\title{
Ethnic Fractionalization, Conflict and Educational Development in Turkey
}

\section{Cem Oyvat}

Senior Lecturer, University of Greenwich, Department of International Business and Economics

Address: Queen Anne Room 164, Old Royal Naval College Park Row, London, United Kingdom, SE10 9LS

E-mail: c.oyvat@greenwich.ac.uk

\section{Hasan Tekgüç}

Associate Professor, Kadir Has University, Department of Economics

Address: Kadir Has Üniversitesi, İISBF Ekonomi Bölümü, Cibali 34083 İstanbul Turkey E-mail: hasan.tekguc@khas.edu.tr 


\title{
Ethnic Fractionalization, Conflict and Educational Development in Turkey
}

\begin{abstract}
We examine the impact of ethnic fractionalization and conflict on limiting the educational development in Southeastern Turkey. Our estimates show that although the armed conflict in the region did not directly hinder education investments, it reduced school enrolment rates at middle and high school levels, while increasing enrolment at the primary school level. Moreover, we show that provinces with higher percentages of Kurdish population received less education investment. These results suggest that the neglect of Kurdish areas is an important factor behind Southeastern Turkey's educational underdevelopment, while land inequality and the armed conflict had mixed effects on education in the region.
\end{abstract}

Keywords: political economy, distribution, conflict, economic development, education. 


\section{Introduction}

Southeastern Turkey has historically been the most underdeveloped region in Turkey. Different studies on province level socioeconomic development (e.g., Ministry of Development, 2013) consistently reflect that the provinces in Southeastern Turkey dominate the lowest ranks in socioeconomic development. ${ }^{1}$ In this study, we will focus on Southeastern Turkey's backwardness in education, since it's often considered as an important determinant of long-term growth (Barro, 2001) and economic development (Sokoloff and Engerman, 2000; Galor, et al., 2009). Moreover, following the capabilities approach (Dreze and Sen, 2002) that conceives 'beings' and 'to be' as important dimensions of welfare, the availability of widespread education facilities is a crucial tool that provides the freedom of being educated. Lower access to education creates inequalities of opportunities that are transferred to the following generations in the developing countries (De Barros, et. al., 2009).

In this article, we contribute to the education and economic development literature by empirically investigating the impact of ethnic fractionalization and conflict on the educational underdevelopment and lack of public investments in Southeastern Turkey. For this purpose, we implement an empirical analysis that includes data from 1970 and 1980years before the insurgency between Kurdistan Workers Party (PKK) and the Turkish state started. This approach gives us a wider perspective that evaluates the Turkish state's policies in Southeastern Turkey, rather than exhibiting the insurgency as the only factor behind the underdevelopment of the region.

The historical evidence starting from 1970 shows that the school enrolment rate in Southeastern provinces has been significantly lower than the provinces in the rest of Turkey (Figure 1). Southeastern Turkey also receives significantly less per capita public education investment (Figure 2), despite the contrary state discourse (Yeğen, 2007; Yayman, 2011) that underlines the need for allocating greater public investment in the region.

However, the institutional structure in Turkey could not prevent the ethnic fractionalization and conflict in Southeastern Turkey, which historically has a Kurdish majority (Figure 3). The modern Republic of Turkey has rejected the Kurdish identity and

\footnotetext{
${ }^{1}$ In our study, we consider the Southeastern provinces to be those that are listed as TRB and TRC according to the classification of Turkish Statistical Institute (Turkstat). These provinces are Gaziantep, Adıyaman, Kilis, Şanlıurfa, Diyarbakır, Mardin, Batman, Şırnak, Siirt, Malatya, Elazı̆̆, Bingöl, Tunceli, Van, Muş, Bitlis and Hakkari.
} 
language (Kirişçi and Winrow, 1997) and tried to assimilate all Muslim minorities under the umbrella of a Turkish identity (Yeğen, 2007). This policy created an environment for ethnic insurgencies (Kirişçi and Winrow, 1997).

Ethnic discrimination might be an impediment to economic development, since ethnic conflict arises when economic and social deprivations coincide with political ones (Stewart, 2005). Ethnic conflict may also influence educational development in a region. It can discourage school attendance, especially of girls, by making the environment outside households dangerous (Shemyakina, 2011; Novelli and Lopes Cardozo, 2008). Furthermore, the central government's ability to bring public education to underserved areas is limited by armed conflict, as insurgents often target schools and teachers as places and agents of central government. In the early 1990s, the PKK killed 136 primary and high school teachers in Eastern and Southeastern Turkey (Kıbris, 2015). We empirically test the impact of both ethnic fractionalization and conflict at province-level with number of teachers per 100 students and number of teacher per 100 school-age children as dependent variables. Furthermore, we also investigate the effect ethnic fractionalization and conflict on school enrolment.

Moreover, similar to the United States (Galor et. al., 2009; Engerman and Sokoloff, 2005), India (Banerjee and Iyer, 2005) and Latin American cases (Wegenast, 2009, 2010; Frankema, 2009) that are widely discussed in the economics literature, Southeastern Turkey historically has a larger land inequality (Figure 4). These studies shows that higher land inequality reduced school enrollment due to both widespread and more acute poverty and lower emphasis on investment in public education in rural areas. Therefore, in our empirical analysis, we also control for the impact of land inequality on educational development for the years in which data for land inequality are available.

The rest of the article is organized as follows: The next section reviews the literature on the effects of ethnic discrimination and armed conflict on education; as well as land inequality in Turkey other countries. Section 3 lays out data, the methodology, and findings. Section 4 discusses the empirical findings and Section 5 concludes the article. 


\section{The double squeeze in Southeastern Turkey}

This section discusses the possible channels that slowed down educational development in Southeastern Turkey. We first discuss why high land inequality is a candidate for explaining the educational underdevelopment in Southeastern Turkey. Next, we examine the Turkish state's policies in Southeastern Turkey, and its approach towards recognition of Kurdish identity and the ethnic insurgency in the region. Then, we discuss the effects of insurgency on educational development in Southeastern Turkey.

\subsection{Southeastern Turkey as a case of high land inequality}

According to Keyder (1987), Turkish agriculture is historically characterized by the predominance of an independent, small-scale peasantry. However, the rural inequality in Southeastern Turkey has been larger than the rest of the country (Figure 4) as the agrarian structure in the region is historically different. Parts of Southeastern Turkey have been host to tribal leaders and large landowners called ăgas (Aydın, 1986). However, unlike many of the countries with a history of colonization (e.g., Engerman and Sokoloff, 2005); land inequality in Southeastern Turkey is not an outcome of racial/ethnic inequalities. Indeed, most of the large landlords in the region are Kurdish locals (Besikci, 1970).

An unequal distribution of land can influence rural inequality through two channels. First, it creates a larger share of very poor households who cannot afford direct and indirect costs of schooling. In regions with inegalitarian agrarian structures, lower income families might wish to have their children educated; however, they may be unable to invest in education. This is because high land inequality also reduces incomes of poor households and leaves them with insufficient sources for education (Galor and Zeira, 1993; Galor and Tsiddon, 1996). Indeed, Banerjee and Iyer (2005) for India and Wegenast (2010) for Brazil and Kourtellos, et al., (2013) in a cross-country study show that higher land inequality reduces enrolment rates. High land inequality could also be an impediment on school enrolment in Turkey, as Kırdar (2009), Smits and Gündüz-Hoşgör (2006) and Ferreira and Gignoux (2013) show that the level of wealth significantly influences enrolment of both girls and boys in Turkey.

Second, high land inequality might lead to underinvestment in public education. Large landlords perceive little benefit in improving educational outcomes (Bowles, 1978). 
This encourages large landlords to use their political influence to prevent public education investments (Galor et. al., 2009). Sokoloff and Engerman (2000) for Americas, Engerman and Sokoloff (2005) for the US, Wegenast (2010) for Brazil and Frankema (2009) for Latin America and Banerjee and Iyer (2005) for India conclude that the countries/states with high land inequality were laggards in terms of educational investments and reforms due to the negative influence of landowning elite.

The wealthy landlords have an institutional influence in Southeastern Turkey (Beşikci, 1970), too. Turkish political parties attempt to earn the support of ăgas who control a part of rural votes in elections (McDowall, 2003). Nevertheless, landlords' political influence declined in recent years as the urban population share increased all over Turkey and rising Kurdish nationalism undermined local elites' electoral influence (Tezcür, 2015). Moreover, the political mechanism outlined above is weaker in Turkey. Unlike most of the countries examined in the literature Turkey does not have a federal state structure. The educational reforms in Turkey are implemented uniformly in all provinces. The educational budgets in each province are determined and provided centrally by the Ministry of National Education.

\subsection{Kurdish population and the conflict}

\subsubsection{A brief overview}

A large part of Southeastern and Eastern Turkey have been dominated by the Kurdish population, which is mainly spread through Iraq, Syria, Iran and Turkey. According to the survey by Konda conducted in 2013, the Kurdish population constitutes 17.7 per cent of the population in Turkey. The construction of the nation state, under the Turkish identity, moved along with a denial of Kurdish identity (Kirişçi and Winrow, 1997) and language (Yeğen, 2007). Kurdish was prohibited and actively prosecuted for most of the twentieth century in Turkey (Hassanpour et al., 1996). During military regime followed by 1980 coup in Turkey, PKK started an armed conflict in 1984. Between 1992 and 1999, the insurgency led to the killings of over 1000 people every year (The Grand National Assembly of Turkey, 2013) with a peak of over 5000 causalities in 1994. The killings included not only Turkish soldiers and PKK guerrillas, but also civilians including civil servants such as teachers (Kirişçi and Winrow, 1997; Özdağ, 2009). In the early 1990s, guerrillas killed 136 teachers 
and burned 238 schools in Eastern and Southeastern Turkey (Kıbris, 2015). The overall insecure environment and the PKK's attacks on public employees created further disincentives for staying in the region (Kıbr1s, 2015; Kıbrıs and Metternich, 2016). Many young teachers and health employees appointed to conflict regions, either quit their jobs or tried to minimize the period they spent in the Southeastern region by any means (sick leave, and so forth).

As a response to the rising insurgency, between 1987-2002, the Turkish state created an Emergency Governorship (OHAL), which ruled all OHAL officers, supervised the security forces and could relocate the citizens in the OHAL region (Aydin and Emrence, 2015) $)^{2}$. Starting from 1985, the Turkish state also armed and paid Kurdish villagers, named 'village guards', to combat the guerrillas in the OHAL region (Marcus, 2007). This extended the insurgency into the civilian population as the village guards and their families were also targeted by PKK attacks. In return, local militias aligned to the Turkish state visited violence on civilians in the OHAL region as well. In addition, the Turkish state emptied a significant part of the insurgency region through waves of forced migration. A report by a major political party, the CHP (1999) notes that 450,000 civilians in the region were subject to forced migration; 820 villages and 2,345 hamlets were vacated. The insurgency continued until the peace negotiations that started between the PKK and the Turkish state in 2012 . With the unilateral ceasefire, the conflict's intensity was significantly reduced for three years. The peace negotiations between the Turkish state and the PKK collapsed in July 2015 and the armed conflict in the region restarted.

\subsubsection{Lack of public investment in the region}

A wide range of literature notes that ethnic fractionalization might lead to a bias in public goods in favor of groups that control the government (e.g., Easterly and Levine, 1997; Alesina and Le Ferrara, 2005; Stewart, 2005). For Turkey, possible public investment bias against Kurds is also a popular political claim; however, quantitative academic evidence is very limited. Kışanak, a leading member of HDP, the main Kurdish party, and the previous

\footnotetext{
${ }^{2}$ OHAL region first covered 8 provinces including- Bingöl, Diyarbakır, Elazı̆̆g, Hakkari, Mardin, Siirt, Tunceli and Van in 1987. Later Adıyaman, Bitlis and Muş were also included in the OHAL region as 'neighboring provinces'. In 1990, the newly created provinces of Şırnak and Batman also became a part of the OHAL region. In 2002, OHAL ended following the declining magnitude of the insurgency.
} 
mayor of Diyarbakır, the largest city in Southeastern Turkey, claims 'the greatest discrimination in this [Kurdish] land is economic discrimination' (Hürriyet, 4 February 2014). A predecessor party of HDP called DTP in their '2007 Political Standpoint Document' claimed that the centralized nation state system of Turkey is the reason behind the socioeconomic gaps in Turkey (Yayman, 2011).

Yeğen (2013) notes that the Turkish state perceived the Kurdish question mainly as a regional underdevelopment problem. In the 1960s new boarding schools in Turkey were mostly constructed in Southeastern Turkey (Besikci, 1970). Starting from the late 1980s, the Turkish state implemented 'education by carrying' policy widely in Southeastern Turkey (Keyder and Üstündağ, 2008). The lion's share of Conditional Cash Payments (62.9 per cent in 2009) that includes educational subsidies on enrolment was given out in Southeastern and Eastern Turkey (Esenyel, 2009) as these are the regions where poverty is very widespread.

However, the outcome-based statistics show attempts to reduce the regional socioeconomic gaps were insufficient. Figure 2 shows persistent regional inequalities in education between 1970 and 2012. The provinces with a Kurdish majority had significantly lower teacher per child ratios ${ }^{3}$. For reducing this gap, during the OHAL periods, Ministry of National Education paid teachers in Southeastern region bonuses for serving under deprivation conditions. In 1998, a new teacher would receive $13.6 \%$ more wages for working in Eastern and Southeastern regions (Hürriyet, 4 April 1998). However, the bonuses for serving in Southeastern Turkey did not continue in the post-OHAL period, although teachers' unions consistently demand to bring the bonuses back (Cumhuriyet, 27 December 2008; Milliyet, 30 March 2010; 13 October 2017).

\subsubsection{Omission of education in mother tongue/first language}

Turkey only very recently, in 2012, allowed Kurdish language teaching in private language courses and as a language elective in schools but still does not implement any Kurdish language instruction in compulsory education. Coşkun et al., (2011) and Çağlayan (2014) note that this policy leads to insufficient communication between Turkish teachers and

\footnotetext{
3 According to our calculations from Turkstat (2017), total personnel expenditures in public educational institutions respectively constituted $75.3 \%$ and $74.3 \%$ of total public education expenditures in primary, middle and high schools in total.
} 
Kurdish students who could not speak Turkish. Therefore, they claim, the real learning of many Kurdish students does not start until they learn Turkish in school.

According to Derince (2012) and Cin and Walker (2016), the language barriers are larger for girls. Due to unequal gender relations, girls are less exposed to the life outside household, which reduces their opportunities to learn Turkish. Indeed, Smits and GündüzHoşgör (2003)'s data reflects that 23.3 per cent of Kurdish women aged 15-49 cannot speak Turkish, whereas only 1.8 per cent of Kurdish men aged 15-49 cannot speak Turkish. Moreover, Kirdar (2009) shows a significant gap between the enrolment rates of Kurdish and Turkish girls even after controlling for many socio-economic variables; however, a similar significant gap does not exist between Kurdish and Turkish boys.

Lastly, Watson (2007) reviews the interplay of language, education and ethnicity and finds out that the suppression of instruction in Kurdish in Middle East (including Turkey) as one of the primary example of education policies that contribute to armed conflict.

\subsubsection{The impact of insurgency on educational development}

The nature of a conflict's impact differs from country to country, and it is hard to find stylized facts relating to civil conflict. Novelli and Lopes Cardozo (2008) list at least three avenues where armed conflict can influence educational chances. Firstly, armed conflict can lead to loss of relatives, direct physical violence etc. Secondly, armed conflict makes travelling to attend schools more dangerous. Thirdly, physical violence can destroy or overtake educational infrastructure. Moreover, Collier et al., (2003) point out that economic growth is likely to decline during armed conflict (or even cause outright recession), which would later also indirectly affect productive public spending. The negative impact on growth might also be permanent as conflict may result in deterioration of political institutions such as spread of corruption. The conflict also increases military spending, which might crowd out education and healthcare spending.

Conflict might also discourage school enrolment by reducing returns on education. Several studies show that the civil conflicts reduced school enrolment rates (Chamarbagwala and Moran, 2011; Verwimp and Van Bavel, 2013). Conflict's impact might also differ with respect to gender and place: worse for boys (in Iraq, Diwakar, 2015); worse for girls (in Tajikistan, Shemyakina, 2011); good for girls (in Nepal, Valente, 2013). 
For Turkey, Berker (2012) finds children exposed to conflict are more likely to graduate from primary school and less likely to graduate from middle and high schools. He speculates that the unexpected positive effect on primary school completion may be due to the fact that many peasants in the smallest hamlets without schools are forced to move to larger settlements with schools. On the other hand, Kayaoğlu (2016) demonstrates that conflict reduced the teacher/student ratio in the OHAL region. Kibris (2015) finds armed conflict damaged the quality of education and reduced university exam scores of high school graduates in the conflict region. She speculates that low exam scores are due to very high teacher turnover and absenteeism of teachers compounded by the conflict. Although the Turkish state aimed to reduce the 'white collar flight' by mandatory service in the conflict region and bonuses for working in there, these attempts were not sufficient as shown in Kibris and Metternich (2016) in a separate study on medical personnel fleeing from the conflict zone.

\section{Empirical analysis}

In this section, we use province-level data to analyze the main factors that lead to the school enrolment and public investment gaps between Southeastern and other provinces in Turkey. In our analysis, we aim to test the impact of land distribution, ethnicity and conflict on school enrolment ratios, per student and per capita education staff in each province.

\subsection{Data and variable selection}

Table 1 summarizes the data used in this study. Inclusion of data from 1970 and 1980 is helpful for controlling for the share of the Kurdish population's impact before the PKK insurgency. We measure the levels of educational attainment with primary, middle and high school net enrolment ratios for boys and girls. We measure land distribution inequality with Gini coefficient ${ }^{4}$. Province-level data for land Gini coefficient is only available for years 1970, 1991 and 2000. Similarly, for the post-1960 period, the province-level share of Kurdish population ratio data is only available for years 1965, 1990 and 2000. Due to data

\footnotetext{
${ }^{4}$ Gini coefficient is an inequality measure taking into account all points of distribution rather than only ratios of certain points of distribution and takes the values between 0 and 1 . Higher values of Gini coefficient imply higher land inequality.
} 
limitations, the regression analysis for school enrolment is restricted to three years (1970, 1990, and 2000). There were 67 provinces in 1970, 73 in 1990 and 81 in 2000. Hence, we have 221 observations in the pooled data set.

We measure the regional gaps in public investment on education by number of teachers per 100 students and number of teachers per 100 school-age children for primary, middle and high school levels. We controlled for the public investment variables with lags of independent variables because the institutional variables might evolve over the longer run. Since we have land Gini coefficient and Kurdish population ratio data only for 1970, 1990, and 2000, we investigate the education investment variables for 1980, 2000 and 2012. There were 67 provinces in 1980, 81 in 2000 and 81 in 2012, hence we have 229 observations in the pooled data set.

The number of teachers per 100 students and number of teachers per 100 school-age children ratios, for 2000 and 2012 and net school enrolment rates for 2000 are obtained from Turkstat (2014b). We construct data for net school enrolment rates in 1970 and 1990 and teacher per 100 students, teacher per 100 children in 1980 by obtaining the student and teacher numbers from the MoNE Statistical Yearbooks (Turkstat, 1976a, 1976b, 1984b, 1984c, 1994a, 2004) and number of school-age children from Population Censuses (Turkstat, 1977, 1993). The net enrolment rates are missing for 1980, since MoNE Statistical Yearbooks do not have age or year of birth data for 1980. The primary and middle schools were combined between 1997 and 2011. We reconstruct primary and middle school data by taking the first five grades as primary and grades between 6 and 8 as middle school. In 2012, the primary and middle schools in Turkey were separated again and accordingly Turkstat provides separate data for these types of schools. Numbers of teachers and students are provided separately by Turkstat for 2012, so we preferred 2012 to 2010.

We control the land distribution with the land Gini coefficient using data from general agricultural censuses constructed for FAO's World Census of Agriculture programs. For 1970, we obtained this data from Çınar and Silier [Köymen] (1979). For 1990, we used Turkstat's (1994b) 1991 General Agricultural Census and for 2000 we used Turkstat's (2014a) 2001 General Agricultural Census.

We control the share of Kurdish population with the share of population whose first language is Kurdish. We used data on share of Kurdish (Kurmanci and Zaza dialects) speakers from Mutlu (1996) and Kibris (2015). After 1965, Turkstat stopped including 
questions regarding mother tongue in the population censuses. Using the population census of 1935 and 1965, Mutlu (1996) predicts that 64.2 per cent of Southeastern and 38.8 per cent of Eastern Turkey is Kurdish, and the Kurds constituted 10.0 per cent of the total population in 1965. Using the internal migration statistics, Mutlu (1996) and Kibris (2015) respectively estimates that the share of the Kurdish population in Turkey has increased to 12.6 per cent in 1990 and 15 per cent in 2000. In order to create share of Kurdish speakers for 1970, we linearly interpolate Mutlu’s 1965 and 1990 estimates.

We measure the intensity of conflict by the number of civilian and soldier deaths per 100,000 in each province within the past 10 years. We combine casualty data from three different sources: Özdağ (2009) provides casualties data for civilians, but only for incidents with 3 or more civilian casualties. Using Directorate General of Press and Information (2015)'s ‘Today's Date' archive, we combined Özdağ (2009)'s data with keyword search on newspaper articles. Summaries of news on Today's Date provide us information for incidents with one or two civilian and military causalities. Finally, we complete the missing province information in Today's Date archive by cross-checking the incidences with the Global Terrorism Database (START, 2015). Our combined data allows us to construct time and place varying series.

We control for province level GDP capita, level of urbanization, population density and population growth for 5-14 year old children in our estimations. We obtained the level of urbanization, population density and population growth in 5-14 year old children data from respective population censuses (Turkstat; 1963, 1977, 1982, 1984a, 1993, 2014b). In order to construct GDP per capita figures, we also combine different studies. Turkstat (2014b) provided GDP per capita data at province level for the period 1987-2001, which covered years 1990 and 2000. Moreover, Özötün (1988) reports province level GDP per capita for 1975 and 1980. Using Özötün's (1988) data for 1975, we deflated 1975 province level GDP per capita to 1970 based on annual growth rates in GDP per capita for Turkey between 1970 and 1975.

Last, we control for the existence of strong levels of patriarchy with the missing girls dummy that we formed. UN (2015) data suggest that average boys-to-girls birth ratio is about 1.06 around the world. If the ratio of 0-4 year old boys-to-girls are two standard 
deviations larger than mean (i.e. more than 1.082) we assigned 1 to the missing girls dummy variable and 0 if the ratio is less than $1.082 .^{5}$

\subsection{Empirical methodology}

A number of studies use provincial level data to test the effectiveness of institutional structure in Turkey. These studies generally use panel data fixed effect regressions to control for unobserved variables in order to focus on the effectiveness of specific policies (Luca and Rodriguez-Pose, 2015; Cesur et al., 2017). The province-level panel data fixed effect regressions are more appropriate when variables exhibit change over time. Unfortunately, two of the variables of interest, province level land inequality and ethnicity, data do not exhibit significant variations over time. On the contrary, they are two important 'sociopolitical cleavages' that affect long-standing regional gaps in the institutional and socioeconomic structure (Güvenç and Kirmanoğlu, 2009). For this reason, we control yearly fixed effects and only broad regional fixed effects ${ }^{6}$ instead of province level fixed effects for examining the factors that affect enrolment rates for boys and girls, teacher per student and teacher per school-age children ratios. We expect that broad regional fixed effects would not absorb all of cross-province variation but they will absorb large differences across regions.

Cin and Walker (2016) show that patriarchal attitudes (including its reflections in curriculum) are prevalent all over Turkey and even more prevalent in Eastern regions (including Northeastern Turkey which is not the focus of this paper). We cannot account for the differential effect of patriarchal attitudes on school enrolment because we do not have a good empirical proxy. Instead, we employ two additional empirical strategies along with the missing women dummy mentioned above: We include dummy variables on broader regions to account for cultural differences between regions including a dummy variable on Eastern. We also estimate school enrolment for boys and girls in separate regressions, which allow us to show the factors explaining the enrolment for boys and girls separately.

\footnotetext{
${ }^{5}$ Unfortunately, the 0-4 years old sex ratio for 1970 is not credible, there are more girls than boys in most provinces. This anomaly is only limited to 0-4 years olds in 1970. As a result, we use $19750-4$ years old boys-to-girls ratio as a proxy for 1970 .

${ }^{6}$ We divide Turkey into five broad regions: West (TR1, TR2, TR3, and TR4), South (TR6), Central (TR5 and TR7), North (TR8 and TR9), and East (TRA, TRB, TRC). As a robustness check, we recalculated OLS estimates without region dummies. Our coefficient estimates are very close to estimates including regional fixed effects (see Supplementary Material A).
} 
In empirical analysis, we first, employ the standard Ordinary Least Squares (OLS) regressions which fits a linear estimate by minimizing the squared errors with clustered standard errors at province level to estimate the net primary, middle and high school enrolment rates for boys and girls with the following equation:

$$
\text { Enroll }_{i t}=\beta_{0}+\beta_{1} \text { Gini }_{i t}+\beta_{2} \operatorname{Kurd}_{i t}+\beta_{3} \operatorname{Conf}_{i t}+\beta_{k} X_{i t k}+\alpha_{t}+\gamma_{j}+e_{i t}
$$

where the effect of land distribution inequality $\left(\right.$ Gini $\left._{i t}\right)$, and the number of causalities per 100000 within the past 10-years $\left(\operatorname{Conf}_{i t}\right)$ and the share of Kurdish population $\left(\operatorname{Kurd}_{i t}\right)$ enrolment rate in each year (t) are controlled for each province (i). $\alpha_{t}$ and $\gamma_{j}$ are respectively year and region dummies. $X_{i t k}$ is a vector of other control variables that are expected to affect the enrolment rates in provinces.

Next, we estimate the factors behind the number of teachers per 100 students and number of teachers per 100 school-age children ratios using OLS regressions with yearly and regional fixed effects. Number of teachers per 100 students $\left(\right.$ Teach/Stu $\left.u_{i t}\right)$ shows the number of teachers that the Turkish state appoints for the given public demand for education. We estimate this variable for primary, middle, high and all school levels with the following equation:

$$
\text { Teach }_{\text {Stu }}=\beta_{1} \operatorname{Gini}_{i(t-1)}+\beta_{2} \operatorname{Kurd}_{i(t-1)}+\beta_{3} \operatorname{Conf}_{i(t-1)}+\beta_{k} X_{i(t-1) k}+\alpha_{t}+\gamma_{j}+e_{i t}
$$

We also test for the number of teachers per 100 school-age children (Teach/Child $\left.{ }_{i t}\right)$ with a similar equation:

Teach $_{\text {Child }}$ it $_{1}=\beta_{1} \operatorname{Gini}_{i(t-1)}+\beta_{2} \operatorname{Kurd}_{i(t-1)}+\beta_{3} \operatorname{Conf}_{i(t-1)}+\beta_{k} X_{i(t-1) k}+\alpha_{t}+\gamma_{j}+e_{i t}$

On the one hand, the number of teachers per 100 student ratio reflects the supply of education investments, i.e. the number of teachers that hired for the existing demand for public education. On the other hand, there are regions where the schools themselves do not exist or are too far for the poor students to attend. The non-availability of schools can be more accurately captured with the number of teachers per 100 school-age children ratio.

Moreover, similar to the existing studies on land inequality (e.g., Easterly, 2007; Galor, et al., 2009; Ramcharan, 2010), we use measures of weather and geography as instruments for land inequality. To conserve space, we only present OLS results in the main text. Two stage least squares with instrumented variables (IV-2SLS) estimates are available in Supplementary Material B. IV-2SLS is a two-step procedure where variable of interest 
(land Gini coefficients) is predicted using other estimates (weather and geography) at the first stage and the predicted values of variable of interest replace the original values of variable of interest in the second stage. Although the magnitudes of the estimated coefficients are different, the results are qualitatively similar.

\subsection{Empirical results}

In this section we present pooled OLS estimates for school enrolment, for number of teachers per 100 student and number of teachers per 100 school-age children ratios.

\subsubsection{School enrolment}

We present the OLS results for school enrolment in Table 2 along with the standardized coefficients $^{7}$ for our main variables ${ }^{89}$. The coefficients on the share of Kurdish speakers are significantly negative for primary school enrolment. The standardized coefficients also show that one standard coefficient increase in the logarithm of share of Kurdish population would respectively reduce the primary school enrolment rate for girls and boys by 0.573 and 0.298 standard deviations. Hence, we observe a larger negative effect of Kurdish speaker share on girls' primary school net enrolment rate compared to boys', which is consistent with the previous studies based on micro data (Smits and Gündüz-Hoşgör, 2006; Kırdar, 2009). This outcome might be due to several reasons. There might be an unfavorable attitude of Kurdish parents' toward their daughter's education due to historical and cultural factors (Kurdar, 2009). Moreover, Kurdish girls are less exposed to the world outside their households than Kurdish boys, which limits their proficiency in Turkish (Derince, 2012). Also Kurdish families might have extra incentives for insisting on their boys' education, since learning advanced level Turkish would relieve an important barrier to Kurdish men for working in

\footnotetext{
${ }^{7}$ The standardized coefficients show how many standard deviations would the dependent variable change if an independent variable changes by one standard deviation. We present the standardized coefficients for all variables in Supplementary Material C.

${ }^{8} \mathrm{We}$ also report the regression results for gross enrolment rate in Supplementary Material D. Table D1 shows that main findings are qualitatively similar for gross enrolment rates.

${ }^{9} \mathrm{We}$ only discuss full models in the main text because of space considerations (in total, we have 14 different dependent variables). In Supplementary Material E we present regression results where we add the explanatory variables to OLS regressions one by one for selected dependent variables.
} 
nonagricultural jobs and any bureaucratic tasks. This might apply less for Kurdish women, since the labor participation rates for women have been very low in Turkey.

Signs of the conflict variable are significantly positive for primary school enrolment. These findings are unexpected but similar to Berker (2012)'s estimates. Rural settlements' migration from smaller rural hamlets to larger villages with primary schools might have led to this outcome. The conflict variable is significant and negative for boys' high school enrolment (at 5\% level). Hence, rising insecurity in the region might also have discouraged families from sending their children to high school.

The effect of the land Gini is negative and significant at 5\% level except for girls' high school enrolment. The coefficient of land Gini for girls' high school enrollment is also negative and roughly the same size with boys' high school enrollment, but it has higher standard errors. According to most specifications, growth in GDP per capita and urbanization in provinces statistically significantly increase school enrolment as expected. 'Missing girls' (boys-to-girls ratio) dummies for patriarchal attitudes are mainly significantly negative. The school enrollment also increases with time, and the coefficient estimate for year 2000 dummy variable is significantly larger than the estimate for 1990 especially for middle school enrollment. This probably reflects the impact of the compulsory education law of 1997, which extended mandatory education from 5 to 8 years. Finally, Eastern region dummy is negative and significant for girls' high school enrolment, which is partially consistent with Cin and Walker (2016). However, for other levels, Eastern region dummy has insignificant and both positive and negative sign, which suggests other variables in the regression analysis already account for observed differences in enrolment rates.

\subsubsection{Teacher-to-Student and Teacher-to-Children ratios}

Table 3 and Table 4 respectively present the OLS results for number of teachers per 100 students and number of teachers per 100 school-age children and the standardized coefficients for our main variables. Contrary to existing literature, the coefficient estimates for the land Gini variable are statistically insignificant and has mixed signs for both ratios. Unlike other countries (e.g., USA and Brazil) studied in the literature, education spending is financed by central government in Turkey. This probably reduces the landlords' capabilities and incentives to block education expenditures. 
The share of Kurdish population in provinces has a significantly negative impact on both ratios except at high school level for the number of teachers per 100 school-age children ratio, which still has negative coefficients. Moreover, for both ratios, the magnitudes of standardized coefficients for the share of Kurdish population are larger than the magnitudes of standardized coefficients for land Gini coefficient and fatalities in the past 10 years. This shows that number of teachers per 100 students and higher teacher per 100 school-age children ratios are more sensitive to differences in the share of Kurdish population. All the other variables have the expected signs: higher GDP per capita leads to higher number of teachers per 100 students and especially higher teacher per 100 school-age children ratios; more densely populated provinces and provinces with faster growth in school-age children have more crowded classrooms.

We generally find insignificant effect of armed conflict on both ratios for middle and high schools. At primary level, our findings indicate that conflict increased the number of teachers per 100 school-age children ratio. This is an unexpected outcome considering that PKK's attacks on teachers made teaching in the conflict region very undesirable for teachers and costly for the Turkish state.

Table 5 presents a separate analysis that uses interaction terms- lags of Kurdish population shares multiplied by the year dummy variables for the years of conflict and postconflict- rather than the conflict variable. Table 5 also shows a negative impact of the Kurdish population, which supports the argument that Kurdish provinces were historically neglected regardless of the conflict. The interaction terms with insurgency years have statistically significantly negative signs for combined school levels, although the coefficients for number of causalities in Table 3 and Table 4 were insignificant. These findings suggest the effects of conflict might be indirect. The conflict might have discouraged white-collar workers from working in all Kurdish majority provinces regardless of the intensity of the conflict. This avoidance of serving in the region could either lead to teacher absenteeism or make the recruitment and retention of teachers in public schools in Kurdish regions costlier.

The impact of conflict at different school levels is more complicated. The intensity of armed conflict significantly positively affected the number of teachers per 100 school-age children ratio (Table 4) in primary schools. Parallel to this, the interaction terms between the share of Kurdish population and 2000 and 2012 dummies are also statistically significantly 
positive (Table 5). Hence, primary education had a different experience compared to secondary education in terms of the conflict's impact.

To summarize, we show that land inequality significantly reduces school enrolment (likely to be through poverty channel), which partially explains the school enrolment gap between Southeastern Turkey and the rest of the country. Moreover, we find a negative relationship between the share of Kurdish speakers in a province and primary school enrolment, which is larger effect for girls. Last, we find a significant positive effect of conflict intensity on primary school enrolment and a significant negative effect of conflict intensity boys' high school enrolment. Our empirical findings support the claims of ethnic discrimination against Kurds. For 1980-2012, we find that a higher share of Kurdish speakers in a province is associated with fewer teachers per 100 students at every school level. Unexpectedly, we also find a significant positive impact of the armed conflict on the number of teachers per 100 school-age children at the primary school level, which is consistent with the Turkish discourse aiming to solve the Kurdish conflict through 'integrating Kurds' by teaching Turkish (Yeğen, 2007; Yayman, 2011). The conflict increased primary school education investments in the region along with the security investments, which would also affect primary school enrolment (Berker, 2012).

\section{Discussion: Mechanisms behind the regional gaps}

In this section, we provide further analysis in order to determine the policy significance of independent variables. For this analysis, we multiplied the coefficient estimates from Tables 2, 3 and 4 with Southeastern Turkey's and the rest of Turkey's means for respective independent variables to decompose the contribution of each independent variable. Then we take the difference of variables' contribution to calculate the contribution of each variable to the difference between Southeastern Turkey and the rest of the country. In our analysis, we focus on the contributions of Kurdish population share, and the number of civilian and security fatalities in conflict and the land Gini coefficient. The "other" factors include both the contribution of control variables as well as the unobserved variables. Following Ziliak and McCloskey (2004)'s critiques on the dismissal of statistically insignificant variables, we include the effects of variables that are statistically insignificant in our analysis. 


\subsection{Enrolment}

Figure 5 and Figure 6 respectively decompose the factors that led to the total difference in school enrolment between Southeastern Turkey and the rest of the country. Figure 6 shows that girls' primary school enrolment rate was around 40 percentage points lower in Southeastern Turkey compared to the rest of Turkey in 1970. The gap declined over time as primary school education became more common. The Kurdish share emerges as the factor that has the largest effect on the regional gaps in girls' primary school enrolment and accounts for 16.2-19.1 percentage points of the gap. The Kurdish share's contribution on boys' primary school enrolment is smaller as it accounts 5.1-6.1 percentage points of the gap. Nevertheless, the share of Kurdish population appears to have a large impact only on the regional gaps in primary school enrolment. Its contribution to the regional gaps is negative for girls' middle or high school enrolment and less than three percentage point for boys' enrolment at middle or high school (Figure 6).

We find consistent evidence for the negative relationship between land distribution inequality and school enrolment. Specifically, land inequality explains 2.7-5.3 percentage points of the regional gap in both girls' and boys' primary and middle school enrolment. The most likely mechanism in this relationship is the poverty channel. The land inequality's effect is only 1.3-2.0 percentage points of the regional gap. This is probably because high school education was not widespread for most of the period between 1970 and 2000 anywhere in Turkey.

Last, the insurgency between the PKK and the Turkish state contributes to the regional gaps by roughly by 4.5 percentage points for girls' middle school and roughly by 3 percentage points for boys' high school enrolment during the conflict era. We find that the conflict helped to partially close the regional gaps in both boys' and girls' primary school enrolment by $7.8-8.4$ percentage points.

\subsection{Teacher-to-student and teacher-to-children ratios}

Figure 7 and Figure 8 reveal that the Kurdish population share contributes to the regional gaps between Southeastern Turkey and other provinces more than land inequality and the intensity of conflict variables. According to our estimates for all levels, 0.53-0.62 of the teacher gap per 100 students between Southeastern and other provinces is explained merely 
by the share of Kurdish population share in Southeastern Turkey. Similarly, the share of Kurdish population reduced the number of teachers per 100 school-age children by 0.69 0.81 in Southeastern Turkey. Our findings support the view that Kurdish majority provinces receive less public spending even after controlling for a host of confounding factors including intensity of armed conflict and land inequality. The effect of ethnicity in allocation of public spending holds for every decade studied in this article.

One potential reason for this preference in allocation of public spending/investment is that electoral returns of public spending in Kurdish majority provinces are low for majority parties. Güvenç and Kirmanoğlu (2009) show that over a long period of time (from 1950 to 2009; 16 general elections) Eastern and Southeastern regions are more likely to support "independents" or candidates from an ever-changing cast of smaller parties emphasizing Kurdish ethnic identity. In other words, there is a limit to how much a national party can garner support from Kurdish majority provinces only with public investment without any overtures to ethnic identity.

The rising conflict can also partially explain the lack of educational investments in provinces with Kurdish majorities. Figures 7 and 8 reflect that the conflict had small direct effect on regional gaps in teacher-to-student and teacher-to-school age population ratios. Nevertheless, the exercise with interaction terms in Table 5 show that the influence of the share of Kurdish population on teacher per hundred student and teacher per 100 school age children ratios are exerted indirectly.

\section{Conclusion}

In this article, we have investigated the role of ethnicity, conflict intensity and agricultural land inequality on the lower rate of school enrolment at every level and less educational investment in Southeastern Turkey. Following the existing literature (e.g. Galor and Zeira, 1993; Galor and Tsiddon, 1996; Kourtellos, et al., 2013), at first glance, higher land inequality in Southeastern Turkey seems to be the primary candidate to explain the underinvestment. Indeed, our results hint that higher level of land inequality affected school enrolment rates by poverty channel. However, we do not find empirical evidence for the effect of land inequality on public investment in education. The governing elite centrally funded and administered public education for nation building purposes (Kirişçi and Winrow, 
1997; Yeğen, 2007). Hence, unlike US South (Engerman and Sokoloff, 2005) or Latin America (Wegenast, 2010) or India (Banerjee and Iyer, 2005), local elites do not need to shoulder the financing of public education locally. Nation building through public education is accompanied by the denial of Kurdish identity and language (Hassanpour et al., 1996), which eventually led to armed conflict and finally lack of instruction in mother tongue probably hampered the scope of learning for Kurdish students (Coşkun et al., 2011; Çağlayan, 2014; Derince, 2012; Cin and Walker, 2016). Indeed, we find that ethnic discrimination and armed conflict empirically better explain the lower public investment in education in Southeastern Turkey. Our empirical results show that an increase in the share of Kurdish population in a province significantly reduces primary school enrolment rates and the negative effect is larger for girls' enrolment rate. Moreover, the results reflect that Turkish state invested disproportionately less in Kurdish majority provinces, despite the contrary rhetoric.

Our results hint that the Turkey should put greater emphasis on reducing the socioeconomic gaps between Southeastern Turkey and the rest of Turkey. This requires greater public spending on education in Southeastern Turkey. Also, the resolution of ongoing ethnic tension and armed struggle in Southeastern Turkey would be an important step in reducing the regional socioeconomic gaps. However, the policies for ending the ethnic conflict in Southeastern Turkey are beyond the scope of this paper. These policies might include a greater recognition of Kurdish cultural identity by the Turkish State and also the possible steps that both the Turkish State and Kurdish Nationalist Movement can take to end the violence in the area. Last, we believe that the education in Kurdish mother tongue might reduce the impediments on education.

Acknowledgements: The authors would like to thank two anonymous reviewers, Alper Yağcı, Bilge Erten, Derya Güngörmez, James K. Boyce, Mehmet Uğur, Nurhan Davutyan, Serkan Demirkılıç and Şemsa Özar for their valuable comments and suggestions.

This research did not receive any specific grant from funding agencies in the public, commercial, or not-for-profit sectors. 


\section{References}

Alesina, A, and E. La Ferrara. 2005. "Ethnic Diversity and Economic Performance.” Journal of Economic Literature 43 (3): 762-800.

Aydın, A and C. Emrence. 2015. Zones of Rebellion: Kurdish Insurgents and the Turkish state. Ithaca: Cornell University Press.

Aydın Z. 1986. Underdevelopment and rural structures in Southeastern Turkey: the household economy in Gisgis and Kalkana. Durham: University of Durham.

Banerjee A and L. Iyer. 2005. "History, Institutions and Economic Performance: The Legacy of Colonial Land Tenure Systems in India.” American Economic Review 95 (4): 1190-1213.

Barro, R. J. 2001. "Human capital and growth." American Economic Review: Papers and Proceedings 91 (2): 12-17.

Berker A. 2012. “Türkiye'deki silahlı çatışmanın eğitimsel erişime etkileri: kuşak analizi' [Armed conflict's effect on access to education in Turkey: cohort analysis]." METU Studies in Development 39 (2): 197-235.

Beşikci İ. 1970. Doğu Anadolu'nun düzeni: sosyo-ekonomik ve etnik temeller [The order of Eastern Anatolia: socio-economic and ethnic roots]. İstanbul: E Yayınları.

Bowles S. 1978. "Capitalist development and educational structure.” World Development 6 (6): 783-796.

Chamarbagwala, R., H. E. Morán. 2011. "The Human Capital Consequences of Civil War: Evidence from Guatemala.” Journal of Development Economics 94 (1): 41-61.

Cesur R., Güneş P. M, Tekin E. and A. Ulker. 2017. “The Value of Socialized Medicine: The Impact of Universal Primary Healthcare Provision on Mortality Rates in Turkey." Journal of Public Economics 150: 75-93.

CHP [Cumhuriyet Halk Partisi]. 1999. Doğu ve Güneydoğu Raporu [Eastern and Southeastern report]. Retrieved from: http://file.setav.org/Files/Pdf/chp-kurt-raporu.pdf (Accessed January 2016).

Cin, F. M. and M. Walker. 2016. 'Reconsidering Girls' Education in Turkey from a Capabilities and Feminist Perspective" International Journal of Educational Development 49: 
134-143.

Collier P., Elliot V.L., Hegre H., Hoeffler A., Reynal-Querol M. and N. Sambanis. 2003. Breaking the Conflict Trap: Civil War and Development Policy. Washington, DC: World Bank and Oxford University Press.

Coşkun V., Derince M.Ş., N. Uçarlar. 2011. Scar of Tongue: Consequences of the Ban on the Use of Mother Tongue in Education and Experiences of Kurdish Students in Turkey. Diyarbakır: Diyarbakır Institute for Political and Social Research.

Çağlayan, H. 2014. Same Home Different Languages, Intergenerational Language Shift Tendencies, Limitations, Opportunities: The Case of Diyarbakır. Diyarbakır: DISA Publications.

Çınar, E.M, O. Silier [Köymen]. 1979. Türkiye tarımında işletmeler arası farklılaşma [Differentiation between units in agriculture]. İstanbul: Boğaziçi Üniversitesi Yayınları.

Cumhuriyet, 27 December 2008. Ĕğitim-Bir Sen'den Çelik'e yanıt [Ĕgitim Bir-Sen replied to Çelik]. Retrieved from http://www.cumhuriyet.com.tr/haber/diger/31252/Egitim-

Bir_Sen_den_Celik_e_yanit.html

De Barros, R. P., Ferreira, F.H.G., Vega J.R.M., J.S. Chanduvi. 2009. Measuring Inequality of Opportunities in Latin America and the Caribbean. Washington, D.C.: World Bank Publications.

Derince, M. Ş. 2012. Anadili Temelli Çokdilli ve Çokdiyalektli Dinamik Ĕ̈itim: Kürt Öğrencilerin Eğitiminde Kullanılabilecek Modeller [Mother-tongue Based Multi-lingual and Multi-dialect Dynamic Education: Models that can be used in the Education of Kurdish Students]. Diyarbakır: DİSA Yayınları

Dinçer, M. A. 2015. Achieving universal education in Turkey Post-2015 challenges. Education Reform Initiative, Istanbul.

Directorate General of Press and Information. 2015. Ayın Tarihi, http://www.ayintarihi.com/ Diwakar, V. 2015. "The Effect of Armed Conflict on Education: Evidence from Iraq." The Journal of Development Studies 51 (12): 1702-1718.

Dreze, J and A. Sen. 2002. India: Development and Participation. New Delhi: Oxford 
University.

Easterly, W and R. Levine. 1997 “Africa's Growth Tragedy: Policies and Ethnic Divisions.” Quarterly Journal of Economics 1203-1250.

Easterly, W. 2007. "Inequality Does Cause Underdevelopment: Insights from A New Instrument.” Journal of Development Economics. 84 (2): 755-776.

Engerman, S.L and K. L. Sokoloff. 2005. "The Evolution of Suffrage Institutions In The New World.” The Journal of Economic History, 65 (04): 891-921.

Esenyel, C. 2009. Türkiye'de Ve Dünyada Şartlı Nakit Transferi Uygulamaları [Conditional Cash Transfer Experiences from Turkey And World] Ankara: Başbakanlık Sosyal Yardımlaşma ve Dayanışma Genel Müdürlüğü.

Ferreira, F. and J. Gignoix. 2013. "The Measurement of Educational Inequality: Achievement and Opportunity." The World Bank Economic Review. 28 (2): 210-246.

Frankema E. 2009. "The Expansion of Mass Education in Twentieth Century Latin America: a Global Comparative Perspective.” Revista de Historia Economica 27 (3): 359-396.

Galor O. and J. Zeira. 1993. "Income Distribution and Macroeconomics." Review of Economic Studies. 60 (1): 35-52.

Galor O., and D. Tsiddon. 1996. "Income Distribution and Growth: The Kuznets Hypothesis Revisited." Economica 103-117.

Galor O., Moav O., and D. Vollrath. 2009. "Inequality in Landownership, the Emergence of Human-capital Promoting Institutions, and the Great Divergence." Review of Economic Studies. 76 (1): 143-179.

Güvenç, M and H. Kirmanoğlu. 2009. Electoral Atlas of Turkey 1950-2009. Istanbul: Istanbul Bilgi University Press.

The Grand National Assembly of Turkey. 2013. Terör ve Şiddet Olayları Kapsamında Yaşam Hakk İhlallerini İnceleme Raporu [Inspection Report on Human Right Abuses During Episodes of Terror and Violence]. (Accessed February 2016). Retrieved from: 
Hassanpour, A, Skutnabb-Kangas, T. and M. Chyet. 1996. "The non-education of Kurds: A Kurdish Perspective.” International Review of Education. 42 (4): 367-379.

Hürriyet, 4 April 1998. En düşük ögrretmen maaşı 72 milyon liraya çıkıyor [The smallest teacher's salary is increasing to 72 million TL]. Retrieved from http://www.hurriyet.com.tr/ekonomi/en-dusuk-ogretmen-maasi-72-milyon-liraya-cikiyor39012722

Hürriyet. 4 February 2014. Kışanak: Kürdistan, Ekonomik Olarak Türkiye'den Ayrılmış [Klşanak: Kurdistan is Separate from Turkey in Terms of Economy]. Retrieved from http://www.hurriyet.com.tr/kisanak-kurdistan-ekonomik-olarak-turkiye-den-ayrilmis$\underline{25742391}$

Kayaoğlu, A. .2016. "Socioeconomic Impact of Conflict: State of Emergency Ruling in Turkey." Defence and Peace Economics. 27 (1): 117-136.

Keyder, Ç. 1987. State and Class in Turkey: A study in Capitalist Development. New York: Verso.

Keyder, Ç. N. and Üstündağ. 2008. Doğu ve Güneydoğu Anadolunun Kalkınmasında Sosyal Politikalar [Social Policy in the development of Eastern and Southeastern Anatolia]. İstanbul: TESEV Report Section IV, Retrieved from:

\section{http://www.spf.boun.edu.tr/_img/1439796150_tesev-gdda-bolum4.pdf}

Kibris, A. 2015. "Conflict Trap Revisited: Civil Conflict and Educational Achievement." Journal of Conflict Resolution 59 (4): 645-670.

Kibris, A. and N. Metternich. 2016. "The flight of white-collars: Civil conflict, availability of medical service providers and public health.” Social Science \& Medicine 149: 93-103.

Kırdar, M.G. (2009) "Explaining ethnic disparities in school enrolment in Turkey." Economic Development and Cultural Change. 57 (2): 297-333.

Kirişçi K., and G.M. Winrow. 1997. The Kurdish Question and Turkey: an Example of a Trans-state Ethnic Conflict. London: Frank Cass. 
Kourtellos, A., Stylianou, I. and C. M. Tan. 2013. "Failure to Launch? The Role of Land Inequality in Transition delays." European Economic Review 62: 98-113.

Luca, D. and A. Rodríguez-Pose. 2015. "Distributive Politics and Regional Development: Assessing the Territorial Distribution of Turkeys Public Investment." The Journal of Development Studies 51 (11): 1518-1540.

Marcus, A. 2007. Blood and Belief: the PKK and the Kurdish Fight for Independence. New York: NYU Press.

McDowall, D. 2003. Modern History of the Kurds. New York: IB Tauris.

Milliyet, 30 March 2010. Zorunlu hizmete zorunlu hizmet tazminat talebi [Demand for service indemnity on mandatory services]. Retrieved from http://www.milliyet.com.tr/zorunlu-hizmete-zorunlu-hizmet-tazminati-talebi-gundem$1218232 /$

Milliyet, 13 October 2017. Eğitim Bir Sen Kayseri 1 Nolu Şube Başkanı Aydın Kalkan [Ĕ̈itim Bir Sen chairman for Kayseri branch no 1, Aydın Kalkan]. Retrieved from http://www.milliyet.com.tr/egitim-bir-sen-kayseri-1-nolu-sube-baskani-kayseri-yerelhaber2336304/

Ministry of Development. 2013. Illerin ve Bölgelerin Sosyo-ekonomik Gelişmişlik Sıralaması Araştırmast, 2011 [Socio-economic Development Ranking of Provinces and Regions in 2011]. Ankara: Bölgesel Gelişme ve Yapısal Uyum Genel Müdürlüğü.

MoNE. 2015. Ministry of National Education Annual Administrative Report, 2014. https://sgb.meb.gov.tr/meb_iys_dosyalar/2015_03/05123201_2014darefaalyetraporu.pdf

Mutlu S. 1996. "Ethnic Kurds in Turkey: A Demographic Study." International Journal of Middle East Studies. 28 (04): 517-541.

National Consortium for the Study of Terrorism and Responses to Terrorism (START). 2015. Global Terrorism Database [Data file]. Retrieved from https://www.start.umd.edu/gtd

Novelli, M. and M.T.A. Lopes Cardozo. 2008. "Conflict, Education and the Global South: New Critical Dimensions" International Journal of Educational Development 28 (4): 473 488.

Özdağ Ü. 2009. Pusu ve Katliamlartn Kronolojisi [The Chronology of Ambushes and 
Massacres]. Ankara: Kripto Yayınevi.

Özötün E. 1988. Distribution of Turkey's Gross Domestic Product by Provinces, 1979-1986. Istanbul: Istanbul Chamber of Industry Publications.

Ramcharan, R. 2010. "Inequality and redistribution: Evidence from US counties and states, 1890-1930." The Review of Economics and Statistics 92 (4): 729-744.

Shemyakina, O. 2011. "The Effect of Armed Conflict on Accumulation of Schooling: Results from Tajikistan.” Journal of Development Economics 95 (2): 186-200.

Smits, J. and A. Gündüz-Hoşgör. 2003. "Linguistic Capital: Language as a Socio-economic Resource Among Kurdish and Arabic Women in Turkey." Ethnic and Racial Studies, 26 (5): 829-853.

Smits, J. and A. Gündüz-Hoşgör. 2006. "Effects of Family Background Characteristics on Educational Participation in Turkey." International Journal of Educational Development. 26 (5): 545-560.

Sokoloff, K. L. and S. L. Engerman. 2000. "History Lessons: Institutions, Factors Endowments, and Paths of Development in the New World." Journal of Economic Perspectives 217-232.

Stewart, F. 2005. Horizontal Inequalities: a Neglected Dimension of Development. UNUWIDER, Wider Perspectives on Global Development. Palgrave Macmillan UK.

Tezcür, G.M. 2015. "Violence and Nationalist Mobilization: the Onset of the Kurdish Insurgency in Turkey." Nationalities Papers, 43 (2): 248-266.

Turkey State Meteorological Service. 2015. TÜMAS Data Base. Retrieved from: http://tumas.mgm.gov.tr/wps/portal/

Turkstat. 1963. Census of Population: Social and Economic Characteristics of Population 23.10.1960. Ankara.

Turkstat. 1976a. National Education Statistics: Primary 1967-71. Ankara.

Turkstat .1976. National Education Statistics: Secondary 1967-71. Ankara.

Turkstat. 1977. Census of Population: Social and Economic Characteristics of Population 
25.10.1970. Ankara.

Turkstat. 1982. Census of Population: Social and Economic Characteristics of Population 25.10.1975. Ankara.

Turkstat. 1984a. Census of Population: Social and Economic Characteristics of Population 25.10.1980. Ankara.

Turkstat. 1984b. National Education Statistics: Primary 1980-81. Ankara.

Turkstat. 1984c. National Education Statistics: Secondary 1980-81. Ankara.

Turkstat. 1993. 1990 Census of Population: Social and Economic Characteristics of Population. Ankara.

Turkstat. 1994a. National Education Statistics 1991-92: Formal Education. Ankara.

Turkstat .1994b. 1991 General Agricultural Census. Retrieved from:

http://kutuphane.tuik.gov.tr/pdf/0013598.pdf

Turkstat. 2004. National Education Statistics 2000-01: Formal Education. Ankara.

Turkstat. 2014a. 2001 General Agricultural Census. Retrieved from:

http://tuik.gov.tr/VeriBilgi.do?alt_id=1003

Turkstat. 2014b. Turkstat Regional Statistics. Retrieved from:

https://biruni.tuik.gov.tr/bolgeselistatistik/sorguGiris.do

Turkstat. 2017. Education Expenditure Statistics, 2017. Retrieved from: http://tuik.gov.tr

UN 2015. United Nations Fertility Data. Retrieved from:

http://data.un.org/Data.aspx?q=sex+ratio+birthandd=PopDivandf=variableID\%3a52

Valente C. 2013. "Education and Civil Conflict in Nepal." The World Bank Economic Review 28 (2): 354-383

Verwimp, P. and J. Van Bavel. 2013. "Schooling, Violent Conflict, and Gender in Burundi." World Bank Economic Review 28 (2): 384-411.

Watson, K. 2007. "Language, Education and Ethnicity: Whose Rights Will Prevail in an Age of Globalisation?" International Journal of Educational Development 27 (3): 252-265. 
Wegenast, T. 2009. “The Legacy of Landlords: Educational Distribution and Development in a Comparative Perspective.” Zeitschrift für vergleichende Politikwissenschaft, 3 (1), 81-107.

Wegenast, T. 2010. "Cana, Café, Cacau: Agrarian Structure and Educational Inequalities in Brazil." Revista de Historia Economica 28 (1): 103-137.

Yayman, H. 2011. Türkiyenin Kürt Sorunu Hafizasl [The memory of Kurdish question in Turkey]. İstanbul: Doğan Kitap.

Yeğen, M. 2007. “Turkish Nationalism and the Kurdish Question.” Ethnic and Racial Studies. 30 (1): 119-151.

Yeğen, M. 2013. Devlet Söyleminde Kürt Sorunu [The Kurdish Question in Turkish State Discourse]. İstanbul: İletişim Yayınları.

Ziliak, S.T. and D. N. McCloskey. 2004. "Size Matters: the Standard Error of Regressions in the American Economic Review." The Journal of Socio-Economics 33 (5): 527-546. 


\title{
Supplementary Materials
}

\section{Supplementary Material A: OLS Results Without Regional Dummy Variables}

\author{
Table A1 here
}

Table A2 here

Table A3 here

\section{Supplementary Material B: IV-2SLS Estimates}

The land inequality is commonly instrumented by the geographical and climatic characteristics (e.g. Easterly, 2007; Ramcharan, 2010). However, these characteristics can also affect other economic variables, which in return affect redistributive policies and bias IV2SLS estimates. Still in this appendix, we instrument the land inequality with geographical and climatic characteristics and report our IV-2SLS estimates for the robustness of our analysis. We expect higher and more volatile temperature to lead to higher land inequality, since these weather conditions might increase the vulnerability of the smaller farmers. Moreover, we expect a higher gap between lowest and highest altitude in a province to reduce the land inequality, since areas with greater variation in altitude might also be hilly which would geographically divide the land and not allow large plantations to exist. Among the possible altitude variables- average altitude, standard deviation of altitude and range of altitude; estimations with range of altitude performs best in the first stage of our analysis. Other measures of land concentration such as standard deviation of rainfall and crop suitability indices, which are commonly used in the literature (Easterly, 2007; Ramcharan, 2010) did not perform well in IV diagnostic tests. We obtained average and standard deviation of temperature from TÜMAS database of Turkey State Meteorological Service (2015). We obtained crop suitability indices from and elevation range from Arbatlı and Gökmen (2015) who have constructed their Turkey indices using FAO Global Agro-Ecological Zones database. 
We estimate net enrolment for primary, middle, high and all school levels with the following IV-2SLS equations:

$$
\begin{aligned}
& \text { Gini }_{i t}=\alpha_{0}+\gamma_{n} Y_{i t n}+\alpha_{1} \text { Kurd }_{i t}+\alpha_{2} \operatorname{Conf}_{i t}+\alpha_{k} X_{i t k}+\alpha_{t}+\gamma_{j}+e_{i t} \\
& \text { Enroll }_{i t}=\beta_{1} \text { Gini }_{i t}+\beta_{2} \text { Kurd }_{i t}+\beta_{3} \text { Conf }_{i t}+\beta_{k} X_{i t k}+\alpha_{t}+\gamma_{j}+e_{i t}
\end{aligned}
$$

where $Y_{i(t-1) n}$ shows the vector of instruments for land Gini coefficient. We present the estimates in Table B1.

\section{Table B1 here}

Next, we estimate teachers per 100 students for primary, middle, high and all school levels with the following IV-2SLS equations:

$$
\begin{aligned}
& \operatorname{Gini}_{i(t-1)}=\alpha_{0}+\gamma_{n} Y_{i(t-1) n}+\alpha_{1} \operatorname{Kurd}_{i(t-1)}+\alpha_{2} \operatorname{Conf}_{i(t-1)}+\alpha_{k} X_{i(t-1) k}+\alpha_{t}+\gamma_{j}+e_{i(t-1)} \\
& \text { Teach } / \text { Stu }_{i t}=\beta_{1} \operatorname{Gini}_{i(t-1)}+\beta_{2} \operatorname{Kurd}_{i(t-1)}+\beta_{3} \operatorname{Conf}_{i(t-1)}+\beta_{k} X_{i(t-1) k}+\alpha_{t}+\gamma_{j}+e_{i t}
\end{aligned}
$$

where $Y_{i(t-1) n}$ shows the vector of instruments for land Gini coefficient. We exhibit our estimates in Table B2.

\section{Table B2 here}

Last, we test for the number of teachers per 100 school-age children (Teach/Child $\left.{ }_{i t}\right)$ with similar equations and present the results in Table B3.

$$
\begin{aligned}
& \operatorname{Gini}_{i(t-1)}=\alpha_{0}+\gamma_{n} Y_{i(t-1) n}+\alpha_{1} \operatorname{Kurd}_{i(t-1)}+\alpha_{2} \operatorname{Conf}_{i(t-1)}+\alpha_{k} X_{i(t-1) k}+\alpha_{t}+\gamma_{j}+e_{i(t-1)} \\
& \text { Teach }_{\text {Child }_{i t}}=\beta_{1} \operatorname{Gini}_{i(t-1)}+\beta_{2} \operatorname{Kurd}_{i(t-1)}+\beta_{3} \operatorname{Conf}_{i(t-1)}+\beta_{k} X_{i(t-1) k}+\alpha_{t}+\gamma_{j}+e_{i t}
\end{aligned}
$$

\section{Table B3 here}


Supplementary Material C: Standardized coefficients for OLS estimates Table C1 here

Table C2 here

Table C3 here

Supplementary Material D: OLS Estimates for gross school enrolment

Table D1 here

Supplementary Material E: Additional OLS Estimates for girls' net middle school enrolment and number of teachers per 100 school-age children

Table E1 here

Supplementary Material F: Correlations between variables

Table F1 here 
Figure 1. Middle school enrolment rates (\%) in provinces in Southeastern Turkey, in provinces with Kurdish population over 50 per cent and their difference with the other provinces (1970, 1990, 2001).
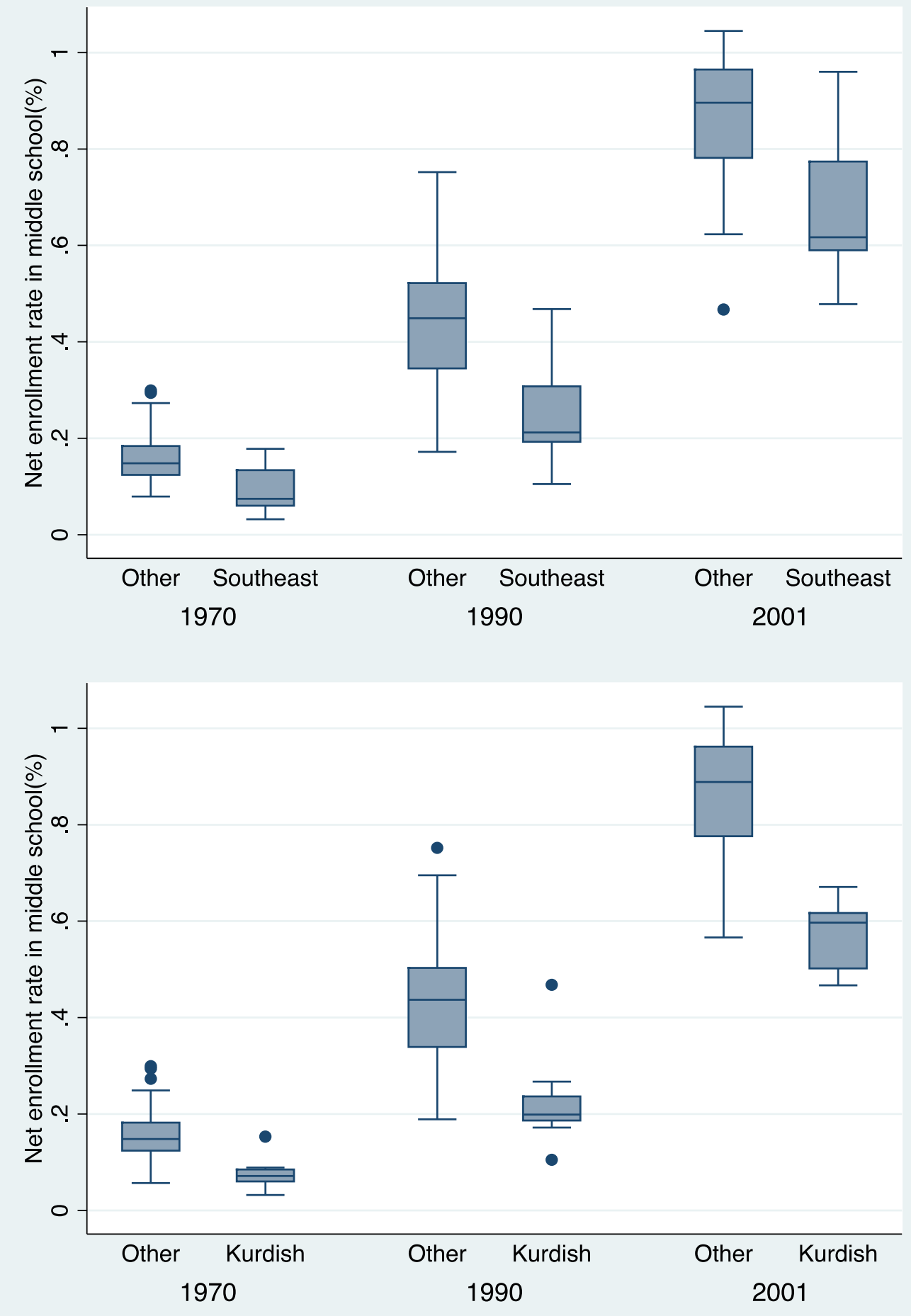

Notes: A one-tailed z-test (at 1\%) shows that middle school net enrolment rates are significantly smaller both for Kurdish and Southeastern provinces. Provinces that are located in Southeastern Turkey are those that are classified as TRB and TRC according to the NUTS classification of Turkstat. The provinces with Kurdish population over 50 per cent are Batman, Bingöl, Bitlis, Diyarbakır, Hakkari, Muş, Siirt, Şırnak, Tunceli and Van. 
Figure 2. Number of teachers per 100 children (6-17) in provinces with Kurdish population over 50 per cent and their difference with the other provinces (1970, 1980, 1990, 2001, and 2012).
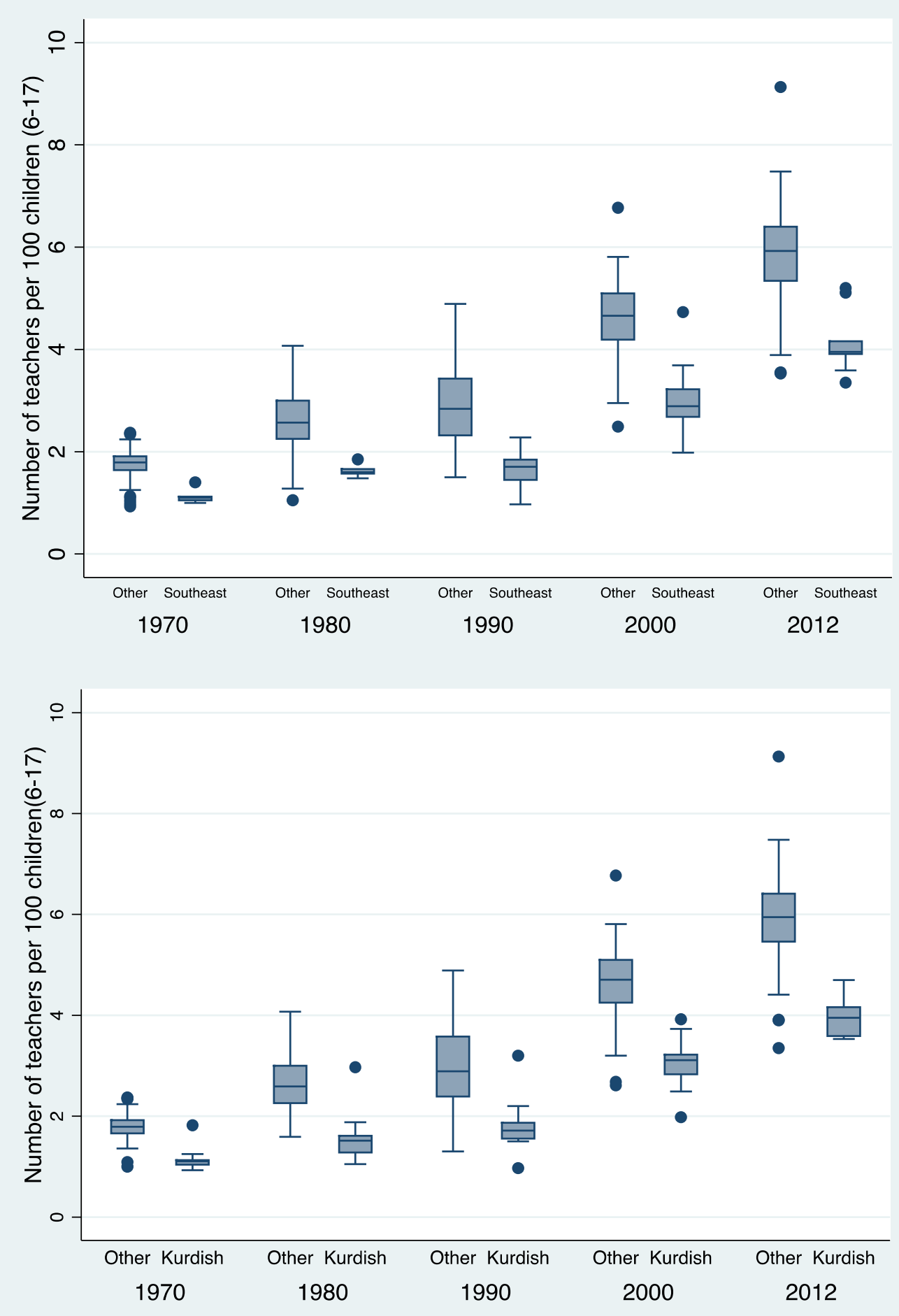

Notes: A one-tailed z-test (at $0.01 \%$ ) shows that the number of teachers per 100 children are significantly smaller both for Kurdish and Southeastern provinces. 
Figure 3. Percentage of Kurdish population according to the 1965 Census.

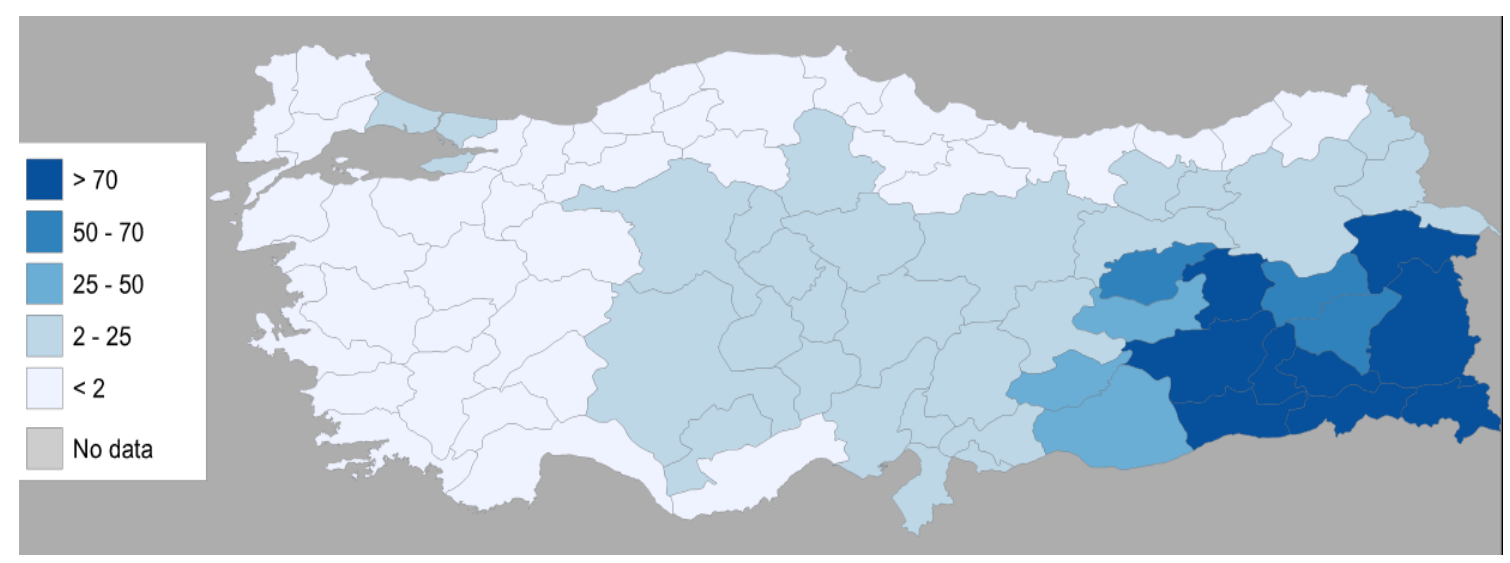

Notes: The population shares are from Mutlu (1996). Between 1989 and 1999, 14 new provinces were created. We assign the Kurdish population shares of mother provinces to the newly created provinces. 
Figure 4. The average land inequality of provinces in Southeastern Turkey, provinces with Kurdish population over 50 per cent and their difference with the other provinces (1970, 1991, and 2001).
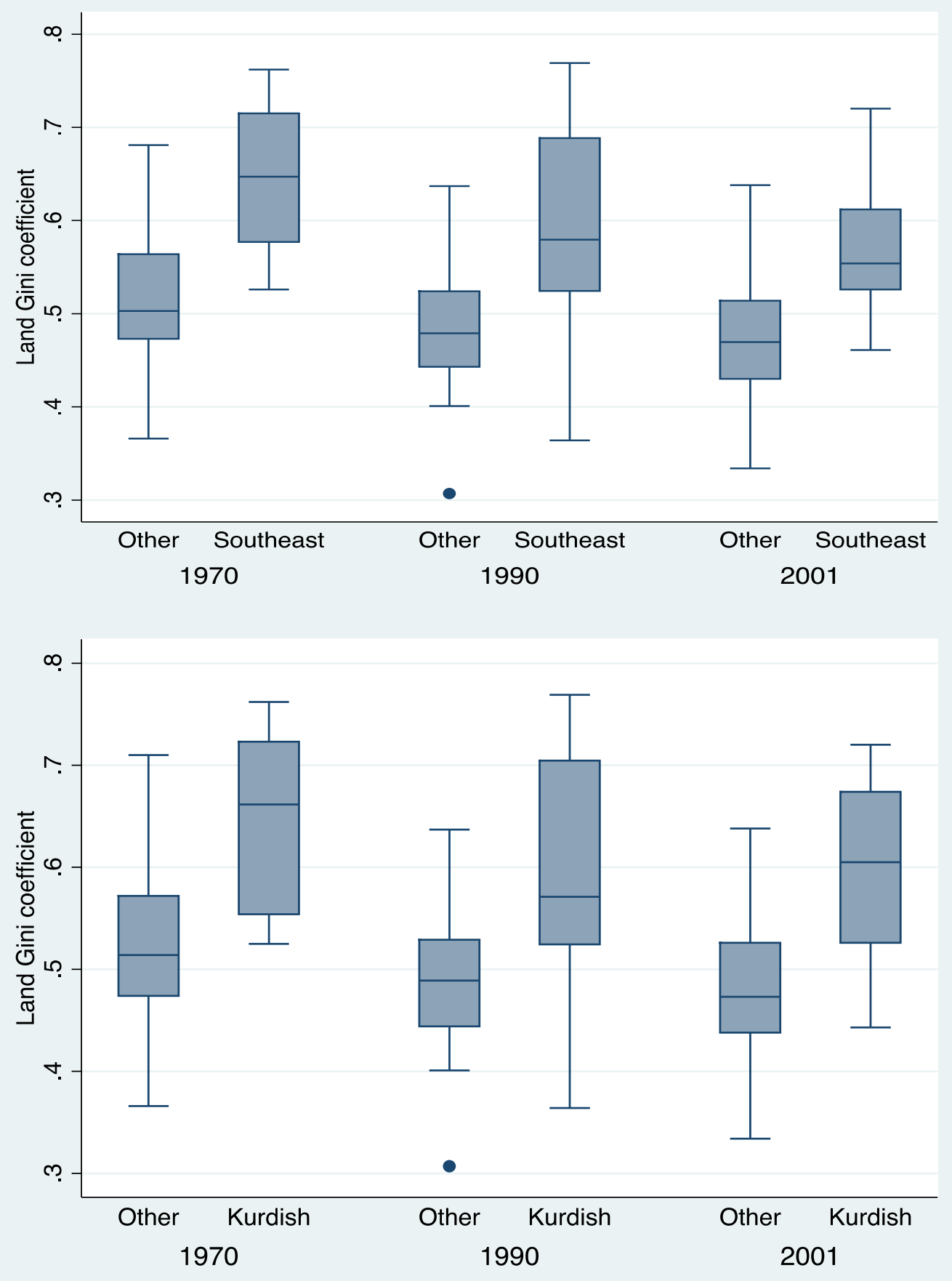

Notes: Land Gini coefficient measures the inequality between the sizes of the farms. Gini coefficient takes a value between 0 and 1 . The value 0 implies farms that are perfectly equal and 1 implies the case that all land is owned by one farm. Hence, higher land Gini coefficient reflects higher land inequality. A one-tailed z-test (at $0.01 \%$ ) shows that the average land Gini coefficients are significantly greater both for Kurdish and Southeastern provinces. 
Figure 5. Girls' Net Enrolment Rate: Predicted contribution of each factor on the differences between Southeastern and rest of Turkey (1970, 1990, 2000)

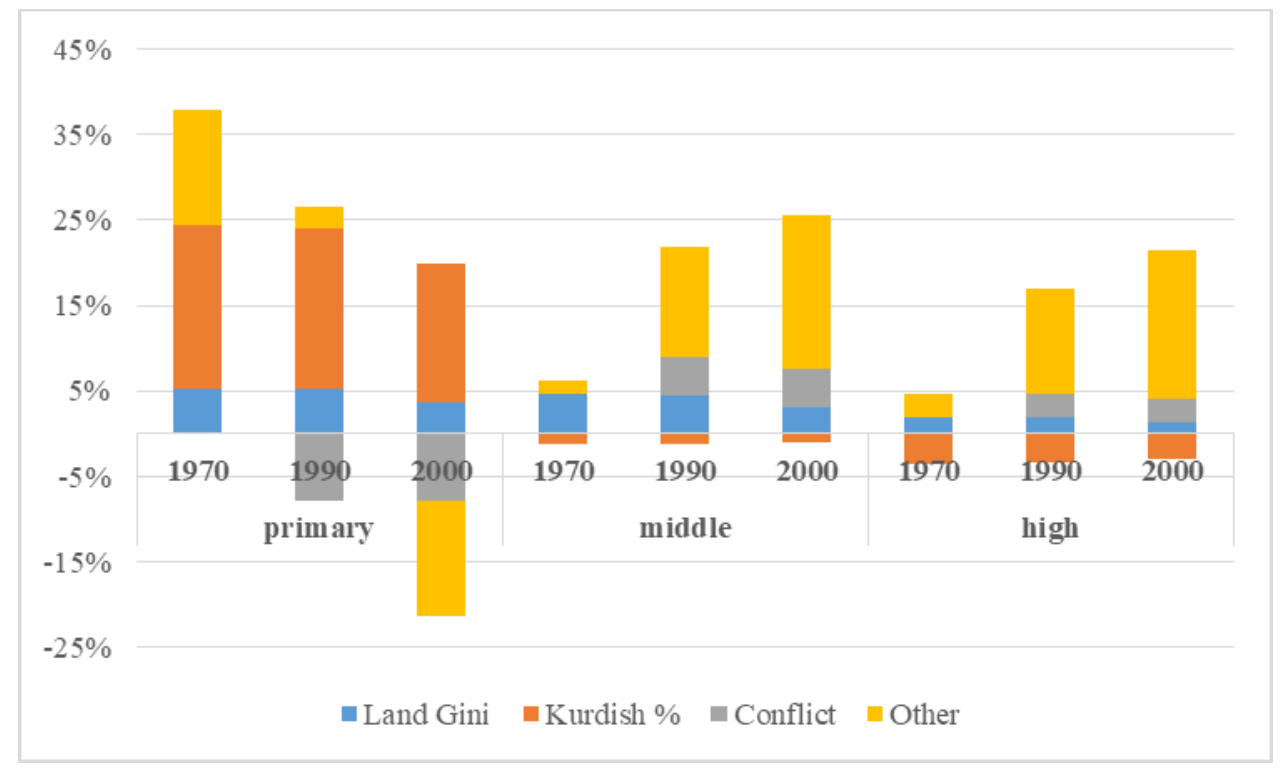

Figure 6. Boys' Net Enrolment Rate: Predicted contribution of each factor on the differences between Southeastern and rest of Turkey (1970, 1990, 2000)

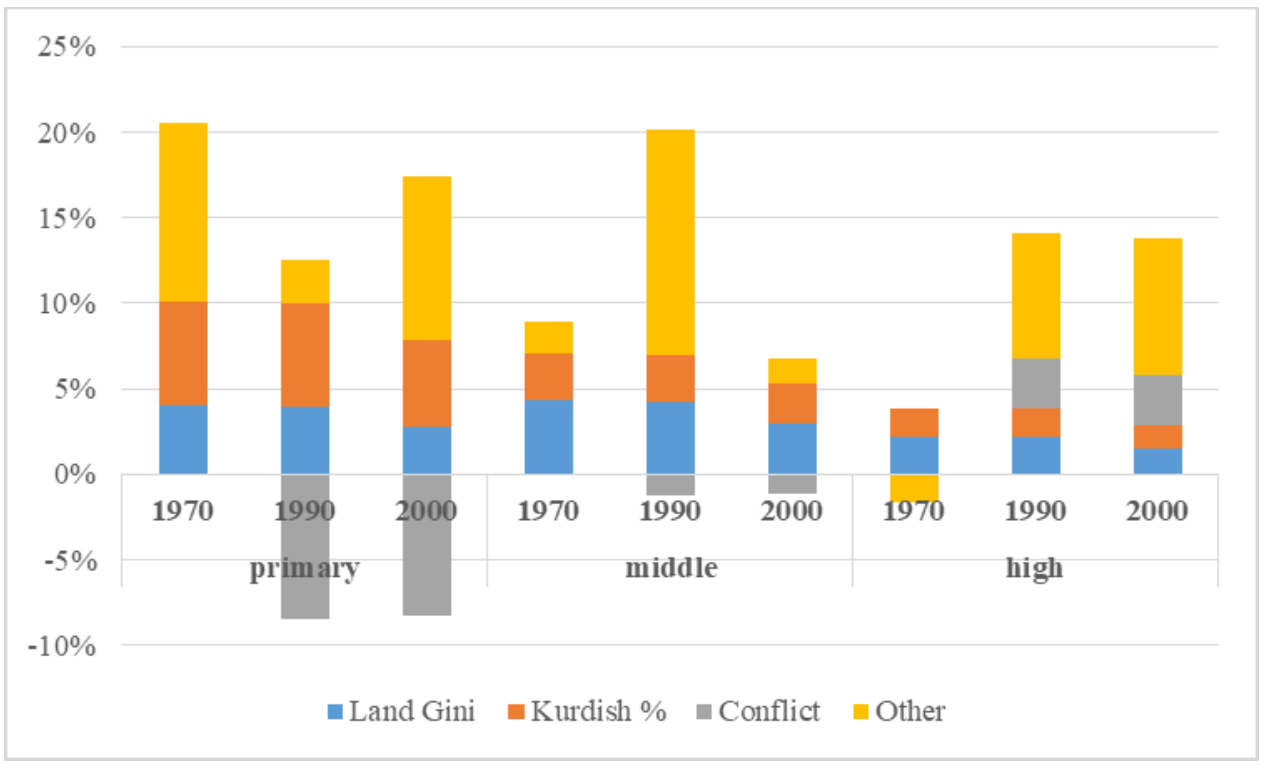


Figure 7. Number of teacher per 100 students gap: Predicted contribution of each factor on the differences between Southeastern and rest of Turkey (1980, 2000, 2012)

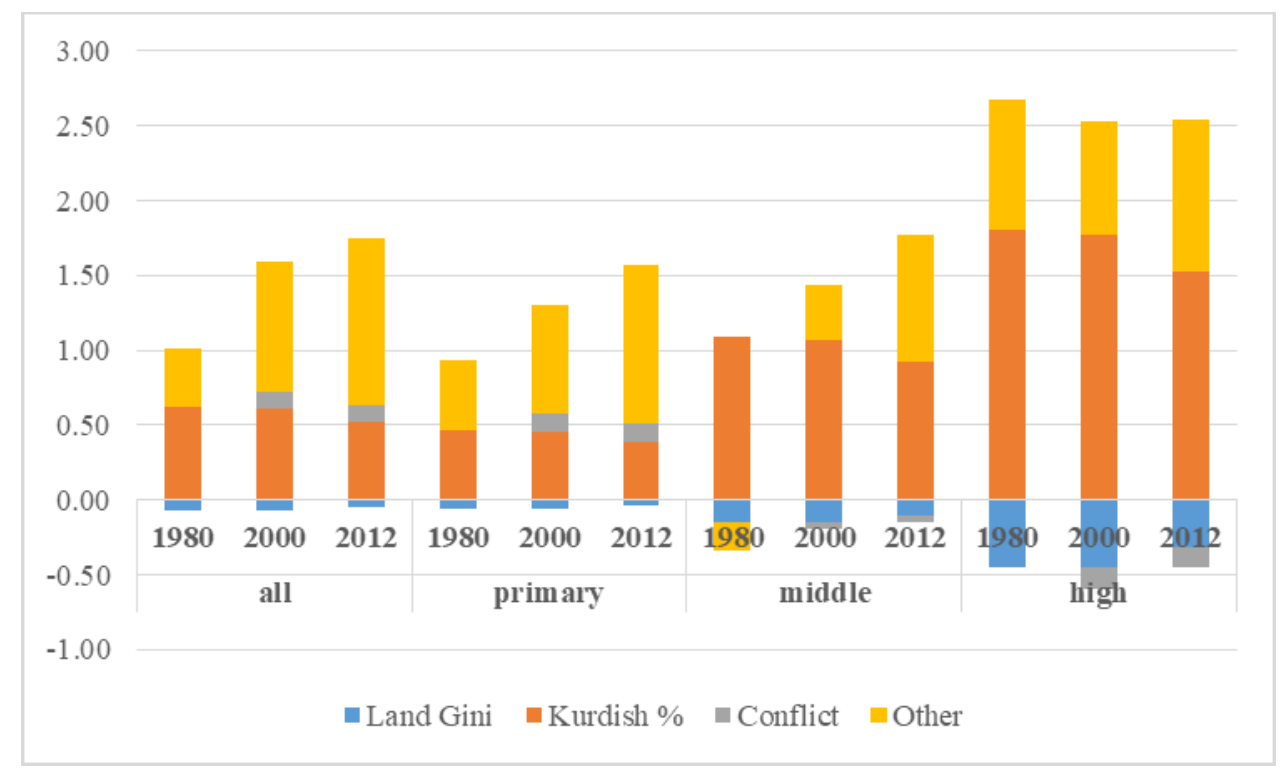

Figure 8. Number of teachers per 100 school-age children Gap: Predicted contribution of each factor on the differences between Southeastern and rest of Turkey (1980, 2000, 2012)

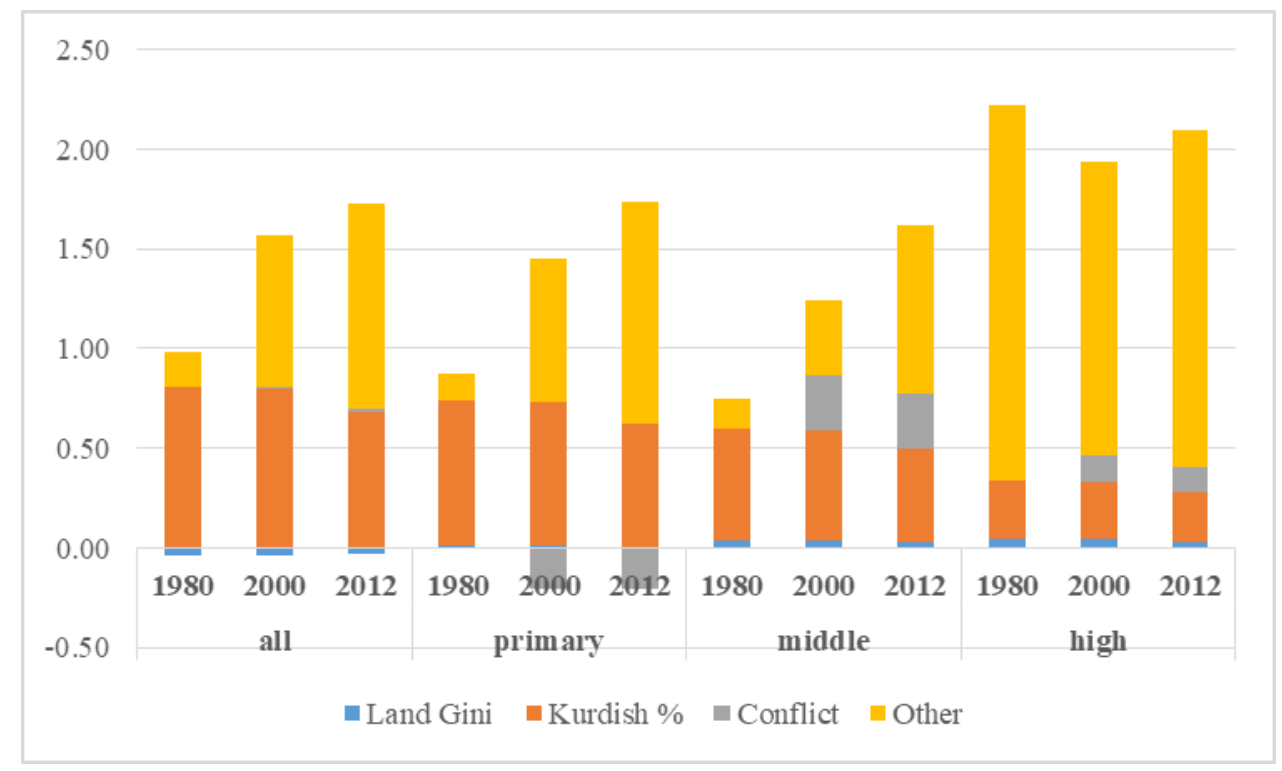


Table 1. Average values for all variables in the study

\begin{tabular}{lccccc}
\hline & $\mathbf{1 9 7 0}$ & $\mathbf{1 9 8 0}$ & $\mathbf{1 9 9 0}$ & $\mathbf{2 0 0 0}$ & $\mathbf{2 0 1 2}$ \\
\hline Teacher per 100 students, all levels & 2.89 & 4.30 & 4.15 & 4.49 & 5.66 \\
Teacher per 100 students, primary & 2.76 & 4.14 & 3.83 & 4.07 & 5.67 \\
Teacher per 100 students, middle & 3.72 & 3.37 & 4.11 & 4.07 & 5.74 \\
Teacher per 100 students, high & 5.41 & 8.52 & 6.15 & 6.29 & 5.58 \\
Teacher per 100 children, all levels & 1.70 & 2.52 & 2.80 & 4.42 & 5.66 \\
Teacher per 100 children, primary & 2.76 & 4.03 & 3.69 & 3.69 & 6.40 \\
Teacher per 100 children, middle & 0.90 & 1.05 & 1.83 & 3.61 & 5.99 \\
Teacher per 100 children, high & 0.44 & 1.21 & 2.21 & 3.34 & 5.40 \\
Girls' net enrolment, primary & 0.66 & & 0.83 & 0.88 & 0.98 \\
Girls' net enrolment, middle & 0.08 & & 0.29 & 0.77 & 0.93 \\
Girls' net enrolment, high & 0.02 & & 0.19 & 0.32 & 0.73 \\
Boys' net enrolment, primary & 0.86 & & 0.89 & 0.92 & 0.98 \\
Boys' net enrolment, middle & 0.20 & & 0.51 & 0.87 & 0.93 \\
Boys' net enrolment, high & 0.07 & & 0.33 & 0.43 & 0.70 \\
Land Gini coefficient & 0.54 & & 0.51 & 0.49 & \\
Kurdish speakers' share & 0.16 & & 0.17 & 0.16 & \\
Tot. fatalities per 100000 & 0 & 0 & 4.86 & 12.19 & 2.58 \\
GDP per capita & 593.47 & 762.30 & 1171.10 & 1416.16 & \\
Urbanization rate & 0.32 & 0.37 & 0.48 & 0.55 & 0.65 \\
Population density & 54.37 & 67.64 & 82.90 & 103.14 & 117.49 \\
Boys-to-girls ratio (age 0-4) & 1.05 & 1.05 & 1.05 & 1.06 & 1.05 \\
School age pop. gr \% ${ }^{\mathrm{a}}$ & 2.52 & 1.29 & 1.18 & -0.89 & -1.79 \\
\hline
\end{tabular}

a: Within the preceding decade. Arithmetic means of province data (not weighted). 
Table 2. OLS Estimates for net school enrolment (1970, 1990, 2000)

\begin{tabular}{|c|c|c|c|c|c|c|}
\hline & \multicolumn{3}{|c|}{ Girls' net enrolment } & \multicolumn{3}{|c|}{ Boys' net enrolment } \\
\hline & Primary & Middle & High & Primary & Middle & High \\
\hline \multirow[t]{2}{*}{ Gini coef. for land distr. } & $-0.311^{*}$ & $-0.270^{*}$ & -0.115 & $-0.235^{*}$ & $-0.253^{*}$ & $-0.129^{*}$ \\
\hline & $(0.135)$ & $(0.122)$ & $(0.075)$ & $(0.096)$ & $(0.100)$ & $(0.063)$ \\
\hline \multirow[t]{2}{*}{ Log of Kurdish \% } & $-0.094^{* *}$ & 0.006 & 0.017 & $-0.030^{*}$ & -0.014 & -0.008 \\
\hline & $(0.015)$ & $(0.011)$ & $(0.010)$ & $(0.014)$ & $(0.010)$ & $(0.008)$ \\
\hline \multirow[t]{2}{*}{ Log of total fatalities } & $0.059^{* *}$ & -0.033 & -0.020 & $0.063^{* *}$ & 0.009 & $-0.022^{* *}$ \\
\hline & $(0.010)$ & $(0.017)$ & $(0.012)$ & $(0.010)$ & $(0.010)$ & $(0.007)$ \\
\hline \multirow[t]{2}{*}{ Boys-to-girls ratio dv } & -0.009 & $-0.054^{*}$ & $-0.030^{*}$ & 0.005 & $-0.035^{*}$ & $-0.028^{*}$ \\
\hline & $(0.031)$ & $(0.022)$ & $(0.014)$ & $(0.025)$ & $(0.013)$ & $(0.012)$ \\
\hline \multirow[t]{2}{*}{ Urban } & 0.102 & $0.170^{*}$ & $0.182^{* *}$ & -0.109 & 0.140 & $0.157^{*}$ \\
\hline & $(0.071)$ & $(0.085)$ & $(0.056)$ & $(0.069)$ & $(0.083)$ & $(0.063)$ \\
\hline \multirow[t]{2}{*}{ Log of gdp pc } & $0.105^{* *}$ & $0.117^{* *}$ & $0.100^{* *}$ & $0.091^{* *}$ & $0.121^{* *}$ & $0.089^{* * *}$ \\
\hline & $(0.025)$ & $(0.023)$ & $(0.017)$ & $(0.022)$ & $(0.019)$ & $(0.017)$ \\
\hline \multirow[t]{2}{*}{ Log of pop. density } & $0.034^{*}$ & -0.009 & -0.021 & $0.057^{* *}$ & 0.004 & $-0.026^{*}$ \\
\hline & $(0.014)$ & $(0.016)$ & $(0.012)$ & $(0.013)$ & $(0.014)$ & $(0.011)$ \\
\hline \multirow[t]{2}{*}{$1990 \mathrm{dv}$} & $0.067^{* *}$ & $0.113^{* *}$ & $0.077^{* *}$ & $-0.055^{*}$ & $0.193^{* *}$ & $0.191^{* * *}$ \\
\hline & $(0.024)$ & $(0.023)$ & $(0.018)$ & $(0.023)$ & $(0.020)$ & $(0.015)$ \\
\hline \multirow[t]{2}{*}{$2000 \mathrm{dv}$} & $0.073^{*}$ & $0.581^{* *}$ & $0.189^{* *}$ & -0.057 & $0.521^{* *}$ & $0.279^{* *}$ \\
\hline & $(0.031)$ & $(0.034)$ & $(0.024)$ & $(0.029)$ & $(0.028)$ & $(0.020)$ \\
\hline \multirow[t]{2}{*}{ South } & -0.004 & 0.000 & -0.008 & -0.007 & -0.011 & 0.010 \\
\hline & $(0.029)$ & $(0.021)$ & $(0.017)$ & $(0.024)$ & $(0.019)$ & $(0.021)$ \\
\hline \multirow[t]{2}{*}{ Central } & 0.007 & -0.012 & -0.036 & 0.003 & 0.009 & 0.012 \\
\hline & $(0.023)$ & $(0.024)$ & $(0.021)$ & $(0.023)$ & $(0.023)$ & $(0.019)$ \\
\hline \multirow[t]{2}{*}{ North } & $-0.097^{* *}$ & -0.019 & -0.006 & $-0.055^{*}$ & -0.008 & $0.041^{* *}$ \\
\hline & $(0.027)$ & $(0.021)$ & $(0.017)$ & $(0.022)$ & $(0.020)$ & $(0.015)$ \\
\hline \multirow[t]{2}{*}{ East } & 0.032 & -0.053 & $-0.069^{*}$ & 0.016 & 0.014 & 0.026 \\
\hline & $(0.033)$ & $(0.031)$ & $(0.027)$ & $(0.033)$ & $(0.029)$ & $(0.029)$ \\
\hline \multirow[t]{2}{*}{ Constant } & 0.149 & $-0.484^{* *}$ & $-0.510^{* *}$ & 0.245 & $-0.464^{* *}$ & $-0.353^{* *}$ \\
\hline & $(0.165)$ & $(0.138)$ & $(0.102)$ & $(0.137)$ & $(0.120)$ & $(0.106)$ \\
\hline \multicolumn{7}{|c|}{ Standardized coefficients for the main variables } \\
\hline Gini coef. for land distr. & -0.147 & -0.072 & -0.063 & -0.182 & -0.074 & -0.064 \\
\hline Log of Kurdish \% & -0.573 & 0.019 & 0.121 & -0.298 & -0.051 & -0.052 \\
\hline Log of total fatalities & 0.281 & -0.089 & -0.113 & 0.490 & 0.027 & -0.109 \\
\hline Number of Observations & 221 & 221 & 221 & 221 & 221 & 221 \\
\hline R-squared & 0.747 & 0.934 & 0.844 & 0.455 & 0.931 & 0.891 \\
\hline
\end{tabular}

Notes: Province-level clustered standard errors in parenthesis. *,** denote 5 and 1 per cent confidence levels, respectively. 
Table 3. OLS Estimates for number of teachers per 100 students $(1980,2000,2012)$

\begin{tabular}{|c|c|c|c|c|}
\hline & \multicolumn{4}{|c|}{ Number of teachers per 100 student } \\
\hline & All levels & Primary & Middle & High \\
\hline \multirow[t]{2}{*}{ Gini coef. for land distr. $\mathrm{t}-1$} & 0.385 & 0.327 & 0.870 & 2.669 \\
\hline & $(0.493)$ & $(0.524)$ & $(0.747)$ & $(1.773)$ \\
\hline \multirow[t]{2}{*}{ Log of Kurdish $\% \mathrm{t}-1$} & $-0.306^{* *}$ & $-0.227^{*}$ & $-0.536^{* *}$ & $-0.888^{* *}$ \\
\hline & $(0.100)$ & $(0.108)$ & $(0.136)$ & $(0.236)$ \\
\hline \multirow[t]{2}{*}{ Log of fatalities prev. 10 years } & -0.080 & -0.091 & 0.034 & 0.103 \\
\hline & $(0.065)$ & $(0.050)$ & $(0.095)$ & $(0.155)$ \\
\hline \multirow[t]{2}{*}{ Urban t-1 } & 0.214 & -0.132 & 0.159 & 1.463 \\
\hline & $(0.490)$ & $(0.439)$ & $(0.715)$ & $(1.266)$ \\
\hline \multirow[t]{2}{*}{$\log$ of gdp pc t-1 } & $0.557^{* *}$ & $0.643^{* *}$ & 0.184 & 0.375 \\
\hline & $(0.119)$ & $(0.121)$ & $(0.139)$ & $(0.315)$ \\
\hline \multirow[t]{2}{*}{ Log of pop. density t-1 } & $-0.504^{* *}$ & $-0.425^{\text {** }}$ & $-0.402^{* *}$ & $-0.829^{* *}$ \\
\hline & $(0.106)$ & $(0.101)$ & $(0.147)$ & $(0.221)$ \\
\hline \multirow[t]{2}{*}{ 5-14 pop. gr. previous 10 years } & $-0.252^{* *}$ & $-0.235^{\text {** }}$ & $-0.232^{* *}$ & $-0.254^{* *}$ \\
\hline & $(0.024)$ & $(0.030)$ & $(0.031)$ & $(0.074)$ \\
\hline \multirow[t]{2}{*}{$2000 \mathrm{dv}$} & $-0.433^{* *}$ & $-0.694^{* *}$ & 0.292 & $-2.765^{* *}$ \\
\hline & $(0.135)$ & $(0.136)$ & $(0.153)$ & $(0.505)$ \\
\hline \multirow[t]{2}{*}{$2012 \mathrm{dv}$} & $0.452^{* *}$ & $0.626^{* *}$ & $1.830^{* *}$ & $-3.619^{* *}$ \\
\hline & $(0.168)$ & $(0.176)$ & $(0.219)$ & $(0.572)$ \\
\hline \multirow[t]{2}{*}{ South } & 0.026 & -0.003 & 0.265 & $-1.058^{*}$ \\
\hline & $(0.213)$ & $(0.223)$ & $(0.258)$ & $(0.495)$ \\
\hline \multirow[t]{2}{*}{ Central } & $-0.296^{*}$ & -0.192 & -0.068 & $-1.324^{* *}$ \\
\hline & $(0.139)$ & $(0.160)$ & $(0.195)$ & $(0.498)$ \\
\hline \multirow[t]{2}{*}{ North } & -0.199 & -0.165 & -0.255 & $-1.206^{*}$ \\
\hline & $(0.142)$ & $(0.149)$ & $(0.181)$ & $(0.478)$ \\
\hline \multirow[t]{2}{*}{ East } & -0.068 & 0.086 & 0.183 & -0.866 \\
\hline & $(0.274)$ & $(0.300)$ & $(0.302)$ & $(0.658)$ \\
\hline \multirow[t]{2}{*}{ Constant } & $3.549^{* *}$ & $2.455^{* *}$ & $4.574^{* *}$ & $10.207^{* *}$ \\
\hline & $(0.808)$ & $(0.790)$ & $(1.067)$ & $(2.078)$ \\
\hline \multicolumn{5}{|c|}{ Standardized coefficients for the main variables } \\
\hline Gini coef. for land distr. $\mathrm{t}-1$ & 0.030 & 0.024 & 0.052 & 0.097 \\
\hline Log of Kurdish \% t-1 & -0.302 & -0.216 & -0.411 & -0.414 \\
\hline Log of fatalities prev. 10 years & -0.058 & -0.064 & 0.020 & 0.036 \\
\hline Number of Observations & 229 & 229 & 229 & 229 \\
\hline R-squared & 0.773 & 0.752 & 0.741 & 0.538 \\
\hline
\end{tabular}

Notes: Province-level clustered standard errors in parenthesis. * ** denote 5 and 1 per cent confidence levels, respectively. 
Table 4. OLS Estimates for teachers per 100 school-age children $(1980,2000,2012)$

\begin{tabular}{|c|c|c|c|c|}
\hline & \multicolumn{4}{|c|}{ Number of teachers per 100 children } \\
\hline & All levels & Primary & Middle & High \\
\hline \multirow[t]{2}{*}{ Gini coef. for land distr. $\mathrm{t}-1$} & 0.247 & -0.058 & -0.213 & -0.262 \\
\hline & $(0.440)$ & $(0.688)$ & $(0.651)$ & $(0.809)$ \\
\hline \multirow[t]{2}{*}{ Log of Kurdish \% t-1 } & $-0.399^{* *}$ & $-0.360^{* *}$ & $-0.277^{* *}$ & -0.145 \\
\hline & $(0.087)$ & $(0.104)$ & $(0.094)$ & $(0.111)$ \\
\hline \multirow[t]{2}{*}{ Log of fatalities prev. 10 years } & -0.008 & $0.155^{* *}$ & -0.208 & -0.094 \\
\hline & $(0.061)$ & $(0.055)$ & $(0.108)$ & $(0.101)$ \\
\hline \multirow[t]{2}{*}{ Urban t-1 } & 0.444 & -0.283 & 0.865 & $2.106^{* *}$ \\
\hline & $(0.459)$ & $(0.484)$ & $(0.694)$ & $(0.658)$ \\
\hline \multirow[t]{2}{*}{ Log of gdp pc t-1 } & $0.554^{* *}$ & $0.740^{* *}$ & $0.567^{* *}$ & $1.283^{* *}$ \\
\hline & $(0.108)$ & $(0.137)$ & $(0.153)$ & $(0.175)$ \\
\hline \multirow[t]{2}{*}{ Log of pop. density t-1 } & $-0.423^{* *}$ & -0.174 & $-0.386^{* *}$ & $-0.543^{* *}$ \\
\hline & $(0.099)$ & $(0.105)$ & $(0.139)$ & $(0.120)$ \\
\hline \multirow[t]{2}{*}{ 5-14 pop. gr. previous 10 years } & $-0.236^{* *}$ & $-0.311^{* *}$ & $-0.288^{* *}$ & $-0.263^{* *}$ \\
\hline & $(0.023)$ & $(0.033)$ & $(0.031)$ & $(0.041)$ \\
\hline \multirow[t]{2}{*}{$2000 \mathrm{dv}$} & $1.201^{* *}$ & $-1.411^{* *}$ & $1.744^{* *}$ & $0.694^{*}$ \\
\hline & $(0.143)$ & $(0.156)$ & $(0.217)$ & $(0.274)$ \\
\hline \multirow[t]{2}{*}{$2012 \mathrm{dv}$} & $2.187^{* *}$ & $1.033^{* *}$ & $3.695^{* *}$ & $2.183^{* *}$ \\
\hline & $(0.159)$ & $(0.203)$ & $(0.240)$ & $(0.315)$ \\
\hline \multirow[t]{2}{*}{ South } & 0.116 & 0.076 & 0.093 & -0.035 \\
\hline & $(0.175)$ & $(0.242)$ & $(0.176)$ & $(0.194)$ \\
\hline \multirow[t]{2}{*}{ Central } & -0.077 & -0.086 & -0.228 & -0.316 \\
\hline & $(0.132)$ & $(0.185)$ & $(0.166)$ & $(0.207)$ \\
\hline \multirow[t]{2}{*}{ North } & -0.151 & $-0.431^{*}$ & -0.262 & 0.257 \\
\hline & $(0.121)$ & $(0.174)$ & $(0.164)$ & $(0.181)$ \\
\hline \multirow[t]{2}{*}{ East } & 0.135 & 0.274 & 0.100 & -0.164 \\
\hline & $(0.247)$ & $(0.265)$ & $(0.245)$ & $(0.314)$ \\
\hline \multirow[t]{2}{*}{ Constant } & 1.486 & 1.156 & -0.020 & $-4.588^{* *}$ \\
\hline & $(0.750)$ & $(0.901)$ & $(0.990)$ & $(1.112)$ \\
\hline \multicolumn{5}{|c|}{ Standardized coefficients for the main variables } \\
\hline Gini coef. for land distr. $\mathrm{t}-1$ & 0.014 & -0.003 & -0.008 & -0.011 \\
\hline Log of Kurdish \% t-1 & -0.285 & -0.254 & -0.137 & -0.077 \\
\hline Log of fatalities prev. 10 years & -0.004 & 0.082 & -0.077 & -0.037 \\
\hline Number of Observations & 229 & 229 & 229 & 229 \\
\hline R-squared & 0.901 & 0.848 & 0.912 & 0.876 \\
\hline
\end{tabular}

Notes: Province-level clustered standard errors in parenthesis. *,** denote 5 and 1 per cent confidence levels, respectively. 
Table 5. Period-based effect of Kurdish speakers'share (OLS estimates; 1980, 2000, 2012)

\begin{tabular}{lcccc}
\hline & All levels & Primary & Middle & High \\
\hline Teacher-to-student & & & & \\
Gini coef. for land distr. t-1 & 0.318 & 0.258 & 0.849 & 2.740 \\
& $(0.506)$ & $(0.535)$ & $(0.753)$ & $(1.743)$ \\
Log of Kurdish \% t-1 & $-0.212^{*}$ & -0.166 & $-0.488^{* *}$ & $-1.000^{* *}$ \\
& $(0.099)$ & $(0.108)$ & $(0.150)$ & $(0.276)$ \\
Log of Kurdish \% t-1 * 2000 & $-0.202^{* *}$ & $-0.143^{*}$ & 0.002 & 0.274 \\
& $(0.060)$ & $(0.063)$ & $(0.100)$ & $(0.267)$ \\
Log of Kurdish \% t-1 * 2012 & $-0.263^{* *}$ & $-0.241^{*}$ & -0.168 & 0.263 \\
& $(0.098)$ & $(0.094)$ & $(0.162)$ & $(0.296)$ \\
Number of Observations & 229 & 229 & 229 & 229 \\
R-squared & 0.782 & 0.758 & 0.744 & 0.540 \\
\hline Teacher-to-children & & & & \\
Gini coef. for land distr. t-1 & 0.209 & 0.009 & -0.308 & -0.426 \\
& $(0.445)$ & $(0.649)$ & $(0.663)$ & $(0.742)$ \\
Log of Kurdish \% t-1 & $-0.306^{* *}$ & $-0.467^{* *}$ & -0.111 & 0.202 \\
& $(0.086)$ & $(0.102)$ & $(0.085)$ & $(0.115)$ \\
Log of Kurdish \% t-1 * 2000 & $-0.135^{*}$ & $0.366^{* *}$ & $-0.528^{* *}$ & $-0.568^{* *}$ \\
& $(0.052)$ & $(0.084)$ & $(0.061)$ & $(0.069)$ \\
Log of Kurdish \% t-1 * 2012 & $-0.218^{* *}$ & $0.174^{*}$ & $-0.270^{*}$ & $-0.845^{* *}$ \\
& $(0.070)$ & $(0.078)$ & $(0.124)$ & $(0.111)$ \\
\hline Number of Observations & 229 & 229 & 229 & 229 \\
R-squared & 0.904 & 0.856 & 0.920 & 0.905 \\
\hline
\end{tabular}

Notes: Province-level clustered standard errors in parenthesis. *,** denote 5 and 1 per cent confidence levels, respectively. All other variables in Table 3 and Table 4, except for the log of fatalities, are included. 


\section{Supplementary Materials}

Table A1. OLS Estimates for Net enrollment without regional dummy variables (1970, 1990, 2000)

\begin{tabular}{lcccccc}
\hline & \multicolumn{3}{c}{ Girls' net enrolment } & \multicolumn{3}{c}{ Boys' net enrolment } \\
\hline & Primary & Middle & High & Primary & Middle & High \\
\hline Gini coef. for land distr. & $-0.296^{*}$ & $-0.251^{*}$ & -0.109 & $-0.231^{*}$ & $-0.265^{* *}$ & -0.134 \\
& $(0.133)$ & $(0.118)$ & $(0.072)$ & $(0.092)$ & $(0.093)$ & $(0.068)$ \\
Log of Kurdish \% & $-0.067^{* *}$ & -0.008 & -0.002 & -0.015 & -0.007 & -0.008 \\
& $(0.012)$ & $(0.008)$ & $(0.006)$ & $(0.010)$ & $(0.008)$ & $(0.006)$ \\
Log of total fatalities & $0.059^{* *}$ & -0.033 & -0.018 & $0.063^{* *}$ & 0.008 & $-0.023^{* *}$ \\
& $(0.010)$ & $(0.017)$ & $(0.012)$ & $(0.010)$ & $(0.009)$ & $(0.007)$ \\
\hline Number of Observations & 221 & 221 & 221 & 221 & 221 & 221 \\
R-squared & 0.717 & 0.933 & 0.838 & 0.430 & 0.930 & 0.886 \\
\hline
\end{tabular}

Notes. All other controls variables are included. Province-level clustered standard errors in parenthesis. *, ** denote 5 and 1 per cent confidence levels, respectively.

Table A2. OLS Estimates for number of teachers per 100 students without regional dummy variables $(1980,2000,2012)$

\begin{tabular}{lcccc}
\hline & \multicolumn{3}{c}{ Number of teachers per 100 student } \\
\hline & All levels & Primary & Middle & High \\
\hline Gini coef. for land distr. t-1 & 0.376 & 0.270 & 1.117 & 1.502 \\
& $(0.487)$ & $(0.521)$ & $(0.760)$ & $(1.883)$ \\
Log of Kurdish \% t-1 & $-0.289^{* *}$ & $-0.165^{*}$ & $-0.460^{* *}$ & $-0.838^{* *}$ \\
& $(0.060)$ & $(0.067)$ & $(0.103)$ & $(0.147)$ \\
Log of fatalities prev. 10 years & -0.056 & -0.078 & 0.035 & 0.221 \\
& $(0.066)$ & $(0.052)$ & $(0.097)$ & $(0.155)$ \\
\hline Number of Observations & 229 & 229 & 229 & 229 \\
R-squared & 0.765 & 0.748 & 0.734 & 0.504 \\
\hline
\end{tabular}

Notes. All other controls variables are included. Province-level clustered standard errors in parenthesis. *,** denote 5 and 1 per cent confidence levels, respectively.

Table A3. OLS Estimates for number of teachers per 100 children without regional dummy variables $(1980,2000,2012)$

\begin{tabular}{lcccc}
\hline & \multicolumn{3}{c}{ Number of teachers per 100 children } \\
\hline & All levels & Primary & Middle & High \\
\hline Gini coef. for land distr. t-1 & 0.333 & -0.033 & -0.171 & -0.349 \\
& $(0.441)$ & $(0.649)$ & $(0.644)$ & $(0.735)$ \\
Log of Kurdish \% t-1 & $-0.339^{* *}$ & $-0.207^{* *}$ & $-0.203^{* *}$ & $-0.219^{* *}$ \\
& $(0.056)$ & $(0.078)$ & $(0.068)$ & $(0.082)$ \\
Log of fatalities prev. 10 years & -0.005 & $0.156^{* *}$ & -0.193 & -0.066 \\
& $(0.063)$ & $(0.053)$ & $(0.109)$ & $(0.099)$ \\
\hline Number of Observations & 229 & 229 & 229 & 229 \\
R-squared & 0.899 & 0.838 & 0.909 & 0.872 \\
\hline
\end{tabular}

Notes. All other controls variables are included. Province-level clustered standard errors in parenthesis. *, ** denote 5 and 1 per cent confidence levels, respectively. 
Table B1. IV-2SLS Estimates for net enrolment (1970, 1990, 2000)

\begin{tabular}{|c|c|c|c|c|c|c|}
\hline & \multicolumn{3}{|c|}{ Girls' net enrolment } & \multicolumn{3}{|c|}{ Boys' net enrolment } \\
\hline & Primary & Middle & High & Primary & Middle & High \\
\hline \multirow[t]{2}{*}{ Gini coef. for land distr. } & -0.178 & -0.469 & -0.359 & -0.272 & $-0.617^{*}$ & -0.454 \\
\hline & $(0.369)$ & $(0.341)$ & $(0.234)$ & $(0.280)$ & $(0.268)$ & $(0.343)$ \\
\hline \multirow[t]{2}{*}{ Log of Kurdish \% } & $-0.101^{* *}$ & 0.016 & 0.029 & -0.028 & 0.005 & 0.008 \\
\hline & $(0.022)$ & $(0.020)$ & $(0.015)$ & $(0.019)$ & $(0.016)$ & $(0.019)$ \\
\hline \multirow[t]{2}{*}{ Log of total fatalities } & $0.059^{* *}$ & $-0.033^{*}$ & -0.020 & $0.063^{* *}$ & 0.010 & $-0.021^{* *}$ \\
\hline & $(0.010)$ & $(0.016)$ & $(0.011)$ & $(0.010)$ & $(0.009)$ & $(0.008)$ \\
\hline \multirow[t]{2}{*}{ Boys-to-girls ratio dv } & -0.010 & $-0.052^{*}$ & -0.028 & 0.005 & $-0.032^{*}$ & $-0.026^{*}$ \\
\hline & $(0.030)$ & $(0.021)$ & $(0.015)$ & $(0.025)$ & $(0.014)$ & $(0.013)$ \\
\hline \multirow[t]{2}{*}{ Urban } & 0.092 & $0.184^{*}$ & $0.199^{* *}$ & -0.106 & $0.165^{*}$ & $0.180^{* *}$ \\
\hline & $(0.073)$ & $(0.085)$ & $(0.056)$ & $(0.068)$ & $(0.084)$ & $(0.066)$ \\
\hline \multirow[t]{2}{*}{ Log of gdp pc } & $0.104^{* *}$ & $0.119^{* *}$ & $0.103^{* *}$ & $0.091^{* *}$ & $0.127^{* *}$ & $0.094^{* *}$ \\
\hline & $(0.024)$ & $(0.022)$ & $(0.018)$ & $(0.021)$ & $(0.020)$ & $(0.019)$ \\
\hline \multirow[t]{2}{*}{ Log of pop. density } & $0.033^{*}$ & -0.007 & -0.019 & $0.057^{* *}$ & 0.008 & -0.023 \\
\hline & $(0.014)$ & $(0.017)$ & $(0.012)$ & $(0.013)$ & $(0.015)$ & $(0.012)$ \\
\hline \multirow[t]{2}{*}{$1990 \mathrm{dv}$} & $0.076^{* *}$ & $0.100^{* *}$ & $0.061^{* *}$ & $-0.057^{*}$ & $0.170^{* *}$ & $0.169^{* *}$ \\
\hline & $(0.028)$ & $(0.028)$ & $(0.022)$ & $(0.028)$ & $(0.024)$ & $(0.029)$ \\
\hline \multirow[t]{2}{*}{$2000 \mathrm{dv}$} & $0.085^{*}$ & $0.563^{* *}$ & $0.166^{* *}$ & -0.061 & $0.487^{* *}$ & $0.249^{* *}$ \\
\hline & $(0.039)$ & $(0.041)$ & $(0.031)$ & $(0.039)$ & $(0.034)$ & $(0.040)$ \\
\hline \multirow[t]{2}{*}{ South } & -0.012 & 0.012 & 0.007 & -0.005 & 0.011 & 0.029 \\
\hline & $(0.035)$ & $(0.028)$ & $(0.021)$ & $(0.028)$ & $(0.027)$ & $(0.032)$ \\
\hline \multirow[t]{2}{*}{ Central } & 0.004 & -0.007 & -0.031 & 0.004 & 0.017 & 0.019 \\
\hline & $(0.022)$ & $(0.024)$ & $(0.019)$ & $(0.021)$ & $(0.024)$ & $(0.018)$ \\
\hline \multirow[t]{2}{*}{ North } & $-0.098^{* *}$ & -0.018 & -0.005 & $-0.055^{* *}$ & -0.006 & $0.042^{* *}$ \\
\hline & $(0.026)$ & $(0.020)$ & $(0.016)$ & $(0.021)$ & $(0.020)$ & $(0.015)$ \\
\hline \multirow[t]{2}{*}{ East } & 0.031 & -0.051 & $-0.066^{* *}$ & 0.016 & 0.017 & 0.028 \\
\hline & $(0.033)$ & $(0.029)$ & $(0.025)$ & $(0.032)$ & $(0.026)$ & $(0.025)$ \\
\hline \multirow[t]{2}{*}{ Constant } & 0.112 & $-0.429^{*}$ & $-0.442^{* *}$ & 0.255 & $-0.362^{*}$ & -0.262 \\
\hline & $(0.218)$ & $(0.178)$ & $(0.120)$ & $(0.155)$ & $(0.143)$ & $(0.145)$ \\
\hline \multicolumn{7}{|c|}{ First stage for Gini coef. for land distr. $t-1$} \\
\hline Average temperature & $0.009^{* *}$ & $0.009^{* *}$ & $0.009^{* *}$ & $0.009^{* *}$ & $0.009^{* *}$ & $0.006^{* *}$ \\
\hline St. dev. temp. & $0.021^{* * *}$ & $0.021^{* *}$ & $0.021^{* *}$ & $0.021^{* *}$ & $0.021^{* *}$ & \\
\hline Elevation range (1000m’s) & 0.007 & 0.007 & 0.007 & 0.007 & 0.007 & \\
\hline \multirow{3}{*}{$\begin{array}{l}\text { Kleibergen-Paap rk LM stat. } \\
\text { Kleibergen-Paap rk Wald F } \\
\text { statistic } \\
\text { Hansen J Statistic }\end{array}$} & $22.874^{* *}$ & $22.874^{* *}$ & $22.874^{* *}$ & $22.874^{* *}$ & $22.874^{* *}$ & $10.650^{* * *}$ \\
\hline & 9.994 & 9.994 & 9.994 & 9.994 & 9.994 & 9.584 \\
\hline & 2.899 & 0.601 & 2.481 & 1.079 & 0.533 & - \\
\hline Number of Observations & 221 & 221 & 221 & 221 & 221 & 221 \\
\hline R-squared & 0.745 & 0.933 & 0.835 & 0.455 & 0.925 & 0.878 \\
\hline
\end{tabular}

Notes: Province-level clustered standard errors in parenthesis. *,** denote 5 and 1 per cent confidence levels, respectively. 3 IVs: Stock-Yogo weak ID critical test values are 22.30 for a $10 \%$ maximal IV size, 12.83 for a $15 \%$ maximal IV size, 9.54 for a $20 \%$ maximal IV size, and 7.80 for $25 \%$ maximal IV size. 1 IV: Stock-Yogo weak ID critical test values are 16.38 for a $10 \%$ maximal IV size, 8.96 for a $15 \%$ maximal IV size, 6.66 for a $20 \%$ maximal IV size, and 5.53 for $25 \%$ maximal IV size. 
Table B2. IV-2SLS Estimates for number of teachers per 100 students (1980, 2000, 2012)

\begin{tabular}{|c|c|c|c|c|}
\hline & \multicolumn{4}{|c|}{ Number of teachers per 100 student } \\
\hline & All levels & Primary & Middle & High \\
\hline \multirow[t]{2}{*}{ Gini coef. for land distr. $\mathrm{t}-1$} & 2.143 & 2.163 & 4.675 & 1.375 \\
\hline & $(1.943)$ & $(1.992)$ & $(2.607)$ & $(5.111)$ \\
\hline \multirow[t]{2}{*}{ Log of Kurdish $\% \mathrm{t}-1$} & $-0.375^{* *}$ & $-0.299^{*}$ & $-0.685^{* *}$ & $-0.837^{* *}$ \\
\hline & $(0.129)$ & $(0.136)$ & $(0.172)$ & $(0.301)$ \\
\hline \multirow[t]{2}{*}{ Log of fatalities prev. 10 years } & -0.086 & $-0.097^{*}$ & 0.021 & 0.108 \\
\hline & $(0.067)$ & $(0.050)$ & $(0.109)$ & $(0.149)$ \\
\hline \multirow[t]{2}{*}{ Urban t-1 } & 0.087 & -0.264 & -0.116 & 1.557 \\
\hline & $(0.498)$ & $(0.434)$ & $(0.780)$ & $(1.179)$ \\
\hline \multirow[t]{2}{*}{ Log of gdp pc t-1 } & $0.545^{* *}$ & $0.631^{* *}$ & 0.159 & 0.383 \\
\hline & $(0.115)$ & $(0.115)$ & $(0.138)$ & $(0.308)$ \\
\hline \multirow[t]{2}{*}{ Log of pop. density t-1 } & $-0.509^{* *}$ & $-0.430^{* *}$ & $-0.413^{* *}$ & $-0.826^{* *}$ \\
\hline & $(0.104)$ & $(0.098)$ & $(0.148)$ & $(0.212)$ \\
\hline \multirow[t]{2}{*}{ 5-14 pop. gr. previous 10 years } & $-0.268^{* *}$ & $-0.252^{* *}$ & $-0.268^{* *}$ & $-0.242^{* *}$ \\
\hline & $(0.027)$ & $(0.031)$ & $(0.034)$ & $(0.081)$ \\
\hline \multirow[t]{2}{*}{$2000 \mathrm{dv}$} & $-0.365^{*}$ & $-0.622^{* *}$ & $0.441^{*}$ & $-2.816^{* *}$ \\
\hline & $(0.164)$ & $(0.160)$ & $(0.207)$ & $(0.506)$ \\
\hline \multirow[t]{2}{*}{$2012 \mathrm{dv}$} & $0.547^{* *}$ & $0.725^{* *}$ & $2.035^{* *}$ & $-3.689^{* *}$ \\
\hline & $(0.212)$ & $(0.214)$ & $(0.265)$ & $(0.599)$ \\
\hline \multirow[t]{2}{*}{ South } & -0.078 & -0.111 & 0.040 & -0.981 \\
\hline & $(0.241)$ & $(0.252)$ & $(0.313)$ & $(0.585)$ \\
\hline \multirow[t]{2}{*}{ Central } & $-0.341^{*}$ & -0.240 & -0.167 & $-1.291^{*}$ \\
\hline & $(0.153)$ & $(0.174)$ & $(0.197)$ & $(0.516)$ \\
\hline \multirow[t]{2}{*}{ North } & -0.221 & -0.188 & -0.304 & $-1.189^{*}$ \\
\hline & $(0.142)$ & $(0.150)$ & $(0.185)$ & $(0.468)$ \\
\hline \multirow[t]{2}{*}{ East } & -0.101 & 0.051 & 0.112 & -0.842 \\
\hline & $(0.267)$ & $(0.294)$ & $(0.297)$ & $(0.660)$ \\
\hline \multirow[t]{2}{*}{ Constant } & $2.930^{* *}$ & $1.810^{*}$ & $3.236^{*}$ & $10.662^{* *}$ \\
\hline & $(0.938)$ & $(0.914)$ & $(1.473)$ & $(2.519)$ \\
\hline \multicolumn{5}{|c|}{ First stage for Gini coef. for land distr. $t-1$} \\
\hline Average temperature & $0.008^{* *}$ & $0.008^{* *}$ & $0.008^{* *}$ & $0.008^{* *}$ \\
\hline St. dev. temp. & $0.021^{* *}$ & $0.021^{* *}$ & $0.021^{* *}$ & $0.021^{* *}$ \\
\hline Elevation range (1000m's) & 0.002 & 0.002 & 0.002 & 0.002 \\
\hline Kleibergen-Paap rk LM statistic. & $23.127^{* *}$ & $23.127^{* *}$ & $23.127^{* *}$ & $23.127^{* *}$ \\
\hline Kleibergen-Paap rk Wald F statistic & 10.637 & 10.637 & 10.637 & 10.637 \\
\hline Hansen J Statistic & 1.347 & 1.349 & 1.047 & 1.155 \\
\hline Number of Observations & 229 & 229 & 229 & 229 \\
\hline R-squared & 0.764 & 0.743 & 0.716 & 0.537 \\
\hline
\end{tabular}

Notes: Province-level clustered standard errors in parenthesis. *,** denote 5 and 1 per cent confidence levels, respectively.3 IVs: Stock-Yogo weak ID critical test values are 22.30 for a $10 \%$ maximal IV size, 12.83 for a $15 \%$ maximal IV size, 9.54 for a $20 \%$ maximal IV size, and 7.80 for $25 \%$ maximal IV size. 
Table B3. IV-2SLS Estimates for number of teachers per 100 school-age children (1980, 2000, 2012)

\begin{tabular}{|c|c|c|c|c|}
\hline & \multicolumn{4}{|c|}{ Number of teachers per 100 school age children } \\
\hline & All levels & Primary & Middle & High \\
\hline Gini coef. for land distr. $\mathrm{t}-1$ & $\begin{array}{c}1.703 \\
(1.721)\end{array}$ & $\begin{array}{c}1.985 \\
(2.061)\end{array}$ & $\begin{array}{l}-0.687 \\
(2.465)\end{array}$ & $\begin{array}{l}-1.821 \\
(2.380)\end{array}$ \\
\hline Log of Kurdish \% t-1 & $\begin{array}{c}-0.456^{* *} \\
(0.115)\end{array}$ & $\begin{array}{c}-0.440^{* *} \\
(0.132)\end{array}$ & $\begin{array}{l}-0.259 \\
(0.138)\end{array}$ & $\begin{array}{l}-0.084 \\
(0.146)\end{array}$ \\
\hline Log of fatalities prev. 10 years & $\begin{array}{l}-0.013 \\
(0.062)\end{array}$ & $\begin{array}{l}0.148^{* * *} \\
(0.053)\end{array}$ & $\begin{array}{l}-0.206^{*} \\
(0.104)\end{array}$ & $\begin{array}{l}-0.089 \\
(0.095)\end{array}$ \\
\hline Urban t-1 & $\begin{array}{c}0.339 \\
(0.457)\end{array}$ & $\begin{array}{l}-0.431 \\
(0.472)\end{array}$ & $\begin{array}{c}0.900 \\
(0.699)\end{array}$ & $\begin{array}{l}2.218^{* *} \\
(0.618)\end{array}$ \\
\hline Log of gdp pc t-1 & $\begin{array}{l}0.544^{* *} \\
(0.105)\end{array}$ & $\begin{array}{l}0.726^{* *} \\
(0.132)\end{array}$ & $\begin{array}{l}0.570^{* *} \\
(0.150)\end{array}$ & $\begin{array}{l}1.294^{* *} \\
(0.173)\end{array}$ \\
\hline Log of pop. density $t-1$ & $\begin{array}{c}-0.427^{* *} \\
(0.096)\end{array}$ & $\begin{array}{l}-0.180 \\
(0.104)\end{array}$ & $\begin{array}{c}-0.385^{* *} \\
(0.136)\end{array}$ & $\begin{array}{c}-0.539^{* * *} \\
(0.117)\end{array}$ \\
\hline 5-14 pop. gr. previous 10 years & $\begin{array}{c}-0.249^{* *} \\
(0.027)\end{array}$ & $\begin{array}{c}-0.330^{* * *} \\
(0.035)\end{array}$ & $\begin{array}{c}-0.284^{* * *} \\
(0.033)\end{array}$ & $\begin{array}{c}-0.249^{* * *} \\
(0.041)\end{array}$ \\
\hline $2000 \mathrm{dv}$ & $\begin{array}{l}1.258^{* *} \\
(0.164)\end{array}$ & $\begin{array}{c}-1.331^{* *} \\
(0.174)\end{array}$ & $\begin{array}{l}1.725^{* *} \\
(0.244)\end{array}$ & $\begin{array}{c}0.633^{*} \\
(0.259)\end{array}$ \\
\hline $2012 \mathrm{dv}$ & $\begin{array}{l}2.266^{* *} \\
(0.192)\end{array}$ & $\begin{array}{l}1.143^{* *} \\
(0.220)\end{array}$ & $\begin{array}{l}3.669^{* *} \\
(0.287)\end{array}$ & $\begin{array}{l}2.099^{* *} \\
(0.311)\end{array}$ \\
\hline South & $\begin{array}{c}0.030 \\
(0.197)\end{array}$ & $\begin{array}{c}-0.045 \\
(0.278)\end{array}$ & $\begin{array}{c}0.121 \\
(0.217)\end{array}$ & $\begin{array}{c}0.058 \\
(0.235)\end{array}$ \\
\hline Central & $\begin{array}{l}-0.115 \\
(0.138)\end{array}$ & $\begin{array}{l}-0.139 \\
(0.195)\end{array}$ & $\begin{array}{c}-0.216 \\
(0.169)\end{array}$ & $\begin{array}{c}-0.276 \\
(0.201)\end{array}$ \\
\hline North & $\begin{array}{l}-0.170 \\
(0.118)\end{array}$ & $\begin{array}{c}-0.457^{* *} \\
(0.172)\end{array}$ & $\begin{array}{l}-0.256 \\
(0.156)\end{array}$ & $\begin{array}{c}0.277 \\
(0.175)\end{array}$ \\
\hline East & $\begin{array}{c}0.107 \\
(0.238)\end{array}$ & $\begin{array}{c}0.236 \\
(0.266)\end{array}$ & $\begin{array}{c}0.109 \\
(0.233)\end{array}$ & $\begin{array}{c}-0.134 \\
(0.294)\end{array}$ \\
\hline Constant & $\begin{array}{c}0.973 \\
(0.890) \\
\end{array}$ & $\begin{array}{c}0.438 \\
(1.102)\end{array}$ & $\begin{array}{c}0.146 \\
(1.153)\end{array}$ & $\begin{array}{c}-4.040^{* *} \\
(1.265)\end{array}$ \\
\hline First stag & or Gini coef. & land distr & & \\
\hline Average temperature & $0.008^{* *}$ & $0.008^{* *}$ & $0.008^{* *}$ & $0.008^{* *}$ \\
\hline St. dev. temp. & $0.021^{* *}$ & $0.021^{* *}$ & $0.021^{* *}$ & $0.021^{* *}$ \\
\hline Elevation range (1000m’s) & 0.002 & 0.002 & 0.002 & 0.002 \\
\hline Kleibergen-Paap rk LM statistic & $23.127^{* *}$ & $23.127^{* *}$ & $23.127^{* * *}$ & $23.127^{* *}$ \\
\hline Kleibergen-Paap rk Wald F statistic & 10.637 & 10.637 & 10.637 & 10.637 \\
\hline Hansen J Statistic & 1.750 & 2.866 & 2.480 & 1.946 \\
\hline Number of Observations & 229 & 229 & 229 & 229 \\
\hline R-squared & 0.898 & 0.842 & 0.912 & 0.874 \\
\hline
\end{tabular}

Notes: Province-level clustered standard errors in parenthesis. *,** denote 5 and 1 per cent confidence levels, respectively. 3 IVs: Stock-Yogo weak ID critical test values are 22.30 for a $10 \%$ maximal IV size, 12.83 for a $15 \%$ maximal IV size, 9.54 for a $20 \%$ maximal IV size, and 7.80 for $25 \%$ maximal IV size. 
Table C1. Standardized coefficients for OLS Estimates for net school enrolment (1970, 1990, 2000)

\begin{tabular}{lcccccc} 
& \multicolumn{3}{c}{ Girls gross enrollment } & \multicolumn{3}{c}{ Boys gross enrollment } \\
& Primary & Middle & High & Primary & Middle & High \\
\hline Gini coef. for land distr. & -0.147 & -0.072 & -0.063 & -0.182 & -0.074 & -0.064 \\
Log of Kurdish \% & -0.573 & 0.019 & 0.121 & -0.298 & -0.051 & -0.052 \\
Log of fatalities prev. 10 & & & & & & \\
years & 0.281 & -0.089 & -0.113 & 0.490 & 0.027 & -0.109 \\
Boys-to-girls ratio dummy & -0.016 & -0.052 & -0.059 & 0.015 & -0.037 & -0.051 \\
Urban & 0.087 & 0.081 & 0.180 & -0.152 & 0.074 & 0.141 \\
Log of gdp pc & 0.359 & 0.222 & 0.392 & 0.505 & 0.257 & 0.317 \\
Log of pop. density & 0.128 & -0.019 & -0.090 & 0.349 & 0.010 & -0.102 \\
1990 dv & 0.172 & 0.162 & 0.227 & -0.229 & 0.308 & 0.511 \\
2000 dv & 0.192 & 0.855 & 0.573 & -0.247 & 0.848 & 0.767 \\
south & -0.007 & 0.000 & -0.014 & -0.018 & -0.011 & 0.017 \\
central & 0.013 & -0.012 & -0.078 & 0.011 & 0.011 & 0.024 \\
north & -0.211 & -0.024 & -0.014 & -0.197 & -0.010 & 0.093 \\
east & 0.079 & -0.073 & -0.195 & 0.063 & 0.022 & 0.066 \\
\hline R-squared & 0.747 & 0.934 & 0.844 & 0.455 & 0.931 & 0.891 \\
Number of Observations & 221 & 221 & 221 & 221 & 221 & 221 \\
\hline
\end{tabular}

Table C2. Standardized coefficients for OLS Estimates for number of teachers per 100 students $(1980,2000,2012)$

\begin{tabular}{lcccc} 
& \multicolumn{4}{c}{ Number of teachers per 100 student } \\
& All levels & Primary & Middle & High \\
\hline Gini coef. for land distr. t-1 & 0.030 & 0.024 & 0.052 & 0.097 \\
Log of Kurdish \% t-1 & -0.302 & -0.216 & -0.411 & -0.414 \\
Log of fatalities prev. 10 years & -0.058 & -0.064 & 0.020 & 0.036 \\
Urban t-1 & 0.031 & -0.018 & 0.018 & 0.099 \\
Log of gdp pc t-1 & 0.309 & 0.344 & 0.079 & 0.098 \\
Log of pop. density t-1 & -0.322 & -0.261 & -0.199 & -0.250 \\
5-14 pop. gr. previous 10 & & & & \\
years & -0.485 & -0.436 & -0.347 & -0.231 \\
2000 dv & -0.185 & -0.285 & 0.096 & -0.556 \\
2012 dv & 0.192 & 0.256 & 0.605 & -0.728 \\
South & 0.007 & -0.001 & 0.055 & -0.134 \\
Central & -0.089 & -0.056 & -0.016 & -0.188 \\
North & -0.071 & -0.057 & -0.071 & -0.203 \\
East & -0.027 & 0.033 & 0.057 & -0.165 \\
\hline R-squared & 0.773 & 0.752 & 0.741 & 0.538 \\
Number of Observations & 229 & 229 & 229 & 229 \\
\hline
\end{tabular}


Table C3. Standardized coefficients for OLS Estimates for teachers per 100 school-age children (1980, 2000, 2012)

\begin{tabular}{lcccc} 
& \multicolumn{4}{c}{ Number of teachers per 100 children } \\
& All levels & Primary & Middle & High \\
\hline Gini coef. for land distr. t-1 & 0.014 & -0.003 & -0.008 & -0.011 \\
Log of Kurdish \% t-1 & -0.285 & -0.254 & -0.137 & -0.077 \\
Log of fatalities prev. 10 years & -0.004 & 0.082 & -0.077 & -0.037 \\
Urban t-1 & 0.046 & -0.029 & 0.062 & 0.162 \\
Log of gdp pc t-1 & 0.223 & 0.294 & 0.158 & 0.385 \\
Log of pop. density t-1 & -0.196 & -0.080 & -0.124 & -0.187 \\
5-14 pop. gr. previous 10 years & -0.329 & -0.429 & -0.279 & -0.274 \\
2000 dv & 0.371 & -0.430 & 0.373 & 0.160 \\
2012 dv & 0.675 & 0.315 & 0.790 & 0.502 \\
South & 0.022 & 0.015 & 0.012 & -0.005 \\
Central & -0.017 & -0.019 & -0.034 & -0.051 \\
North & -0.039 & -0.110 & -0.047 & 0.049 \\
East & 0.039 & 0.079 & 0.020 & -0.036 \\
\hline R-squared & 0.901 & 0.848 & 0.912 & 0.876 \\
Number of Observations & 229 & 229 & 229 & 229 \\
\hline
\end{tabular}


Table D1. OLS Estimates for gross school enrolment (1970, 1990, 2000)

\begin{tabular}{|c|c|c|c|c|c|c|}
\hline & \multicolumn{3}{|c|}{ Girls' net enrolment } & \multicolumn{3}{|c|}{ Boys' net enrolment } \\
\hline & Primary & Middle & High & Primary & Middle & High \\
\hline \multirow[t]{2}{*}{ Gini coef. for land distr. } & $-0.364^{*}$ & $-0.320^{*}$ & -0.152 & $-0.261^{*}$ & $-0.317^{* *}$ & $-0.174^{*}$ \\
\hline & $(0.162)$ & $(0.149)$ & $(0.102)$ & $(0.104)$ & $(0.126)$ & $(0.079)$ \\
\hline \multirow[t]{2}{*}{ Log of Kurdish \% } & $-0.118^{* *}$ & 0.008 & 0.018 & -0.029 & -0.018 & -0.019 \\
\hline & $(0.020)$ & $(0.014)$ & $(0.013)$ & $(0.018)$ & $(0.012)$ & $(0.011)$ \\
\hline \multirow[t]{2}{*}{ Log of total fatalities } & $0.082^{* *}$ & $-0.043^{*}$ & -0.022 & $0.079^{* *}$ & 0.003 & -0.018 \\
\hline & $(0.012)$ & $(0.020)$ & $(0.016)$ & $(0.013)$ & $(0.011)$ & $(0.010)$ \\
\hline \multirow[t]{2}{*}{ Boys-to-girls ratio dv } & 0.009 & $-0.068^{*}$ & -0.035 & 0.003 & -0.039 & -0.019 \\
\hline & $(0.043)$ & $(0.030)$ & $(0.019)$ & $(0.033)$ & $(0.022)$ & $(0.020)$ \\
\hline \multirow[t]{2}{*}{ Urban } & 0.058 & $0.217^{*}$ & $0.225^{* *}$ & $-0.209^{* *}$ & 0.178 & $0.208^{*}$ \\
\hline & $(0.080)$ & $(0.098)$ & $(0.076)$ & $(0.076)$ & $(0.098)$ & $(0.090)$ \\
\hline \multirow[t]{2}{*}{ Log of gdp pc } & $0.099^{* *}$ & $0.147^{* *}$ & $0.134^{* *}$ & $0.074^{* *}$ & $0.155^{* *}$ & $0.116^{* *}$ \\
\hline & $(0.032)$ & $(0.027)$ & $(0.024)$ & $(0.025)$ & $(0.024)$ & $(0.025)$ \\
\hline \multirow[t]{2}{*}{ Log of pop. density } & $0.043^{*}$ & -0.023 & -0.023 & $0.070^{* *}$ & -0.008 & $-0.032^{*}$ \\
\hline & $(0.018)$ & $(0.020)$ & $(0.015)$ & $(0.016)$ & $(0.016)$ & $(0.015)$ \\
\hline \multirow[t]{2}{*}{$1990 \mathrm{dv}$} & -0.034 & $0.069^{* *}$ & $0.107^{* *}$ & $-0.195^{* *}$ & $0.063^{* *}$ & $0.253^{* *}$ \\
\hline & $(0.032)$ & $(0.026)$ & $(0.023)$ & $(0.027)$ & $(0.023)$ & $(0.020)$ \\
\hline \multirow[t]{2}{*}{$2000 \mathrm{dv}$} & $-0.086^{*}$ & $0.527^{* *}$ & $0.238^{* *}$ & $-0.255^{\text {** }}$ & $0.398^{* *}$ & $0.384^{* *}$ \\
\hline & $(0.040)$ & $(0.041)$ & $(0.032)$ & $(0.032)$ & $(0.035)$ & $(0.027)$ \\
\hline \multirow[t]{2}{*}{ South } & 0.024 & 0.003 & 0.001 & 0.024 & 0.004 & 0.044 \\
\hline & $(0.036)$ & $(0.025)$ & $(0.021)$ & $(0.029)$ & $(0.025)$ & $(0.031)$ \\
\hline \multirow[t]{2}{*}{ Central } & 0.041 & -0.021 & -0.042 & 0.033 & 0.016 & 0.032 \\
\hline & $(0.028)$ & $(0.027)$ & $(0.026)$ & $(0.026)$ & $(0.028)$ & $(0.028)$ \\
\hline \multirow[t]{2}{*}{ North } & $-0.085^{* *}$ & -0.013 & 0.000 & -0.025 & 0.004 & $0.073^{* *}$ \\
\hline & $(0.032)$ & $(0.024)$ & $(0.022)$ & $(0.025)$ & $(0.024)$ & $(0.023)$ \\
\hline \multirow[t]{2}{*}{ East } & $0.088^{*}$ & -0.075 & -0.069 & 0.059 & 0.031 & 0.080 \\
\hline & $(0.044)$ & $(0.041)$ & $(0.037)$ & $(0.042)$ & $(0.035)$ & $(0.043)$ \\
\hline \multirow[t]{2}{*}{ Constant } & 0.400 & $-0.546^{* *}$ & $-0.698^{* *}$ & $0.566^{* *}$ & $-0.438^{* *}$ & $-0.440^{* *}$ \\
\hline & $(0.204)$ & $(0.157)$ & $(0.144)$ & $(0.165)$ & $(0.147)$ & $(0.155)$ \\
\hline Number of Observations & 221 & 221 & 221 & 221 & 221 & 221 \\
\hline R-squared & 0.549 & 0.912 & 0.845 & 0.483 & 0.889 & 0.885 \\
\hline
\end{tabular}

Notes. Province-level clustered standard errors in parenthesis. $*$, ** denote 5 and 1 percent confidence levels, respectively. 
Table E1. OLS estimates for girls' middle school enrollment (1970, 1990, 2000)

\begin{tabular}{|c|c|c|c|c|c|c|c|c|}
\hline & Gini & Kurdish & Conflict & Gini + 1 & Gini +2 & Gini +3 & Gini +4 & Table 2, C2 \\
\hline Gini coef. for land distr. & $\begin{array}{c}-0.156 \\
(0.130)\end{array}$ & & & $\begin{array}{c}-0.122 \\
(0.123)\end{array}$ & $\begin{array}{l}-0.260^{*} \\
(0.120)\end{array}$ & $\begin{array}{c}-0.289^{*} \\
(0.111)\end{array}$ & $\begin{array}{l}-0.286^{*} \\
(0.109)\end{array}$ & $\begin{array}{l}-0.270^{*} \\
(0.122)\end{array}$ \\
\hline Log of Kurdish \% & & $\begin{array}{c}-0.022 \\
(0.016)\end{array}$ & & & & & & $\begin{array}{c}0.006 \\
(0.011)\end{array}$ \\
\hline Log of fatalities prev. 10 years & & & $\begin{array}{c}-0.059^{* *} \\
(0.017)\end{array}$ & & & & & $\begin{array}{l}-0.033 \\
(0.017)\end{array}$ \\
\hline Boys-to-girls ratio dummy & & & & $\begin{array}{c}-0.091^{* *} \\
(0.027)\end{array}$ & $\begin{array}{c}-0.087^{* *} \\
(0.026)\end{array}$ & $\begin{array}{c}-0.063^{* *} \\
(0.020)\end{array}$ & $\begin{array}{c}-0.062^{* *} \\
(0.020)\end{array}$ & $\begin{array}{l}-0.054^{*} \\
(0.022)\end{array}$ \\
\hline Urban & & & & & $\begin{array}{l}0.332^{* * *} \\
(0.074)\end{array}$ & $\begin{array}{c}0.110 \\
(0.078)\end{array}$ & $\begin{array}{c}0.120 \\
(0.088)\end{array}$ & $\begin{array}{c}0.170^{*} \\
(0.085)\end{array}$ \\
\hline Log of gdp pc & & & & & & $\begin{array}{l}0.141^{\text {** }} \\
(0.019)\end{array}$ & $\begin{array}{l}0.142^{* *} \\
(0.019)\end{array}$ & $\begin{array}{l}0.117^{* *} \\
(0.023)\end{array}$ \\
\hline Log of pop. density & & & & & & & $\begin{array}{c}-0.004 \\
(0.016)\end{array}$ & $\begin{array}{c}-0.009 \\
(0.016)\end{array}$ \\
\hline $1990 \mathrm{dv}$ & $\begin{array}{l}0.212^{\text {** }} \\
(0.014)\end{array}$ & $\begin{array}{l}0.220^{* * *} \\
(0.012)\end{array}$ & $\begin{array}{l}0.235^{* *} \\
(0.011)\end{array}$ & $\begin{array}{l}0.205^{* *} \\
(0.014)\end{array}$ & $\begin{array}{l}0.146^{* *} \\
(0.018)\end{array}$ & $\begin{array}{l}0.094^{* *} \\
(0.018)\end{array}$ & $\begin{array}{l}0.093^{* *} \\
(0.019)\end{array}$ & $\begin{array}{l}0.113^{* *} \\
(0.023)\end{array}$ \\
\hline $2000 \mathrm{dv}$ & $\begin{array}{l}0.697^{\text {** }} \\
(0.020)\end{array}$ & $\begin{array}{l}0.709^{* *} \\
(0.018)\end{array}$ & $\begin{array}{l}0.741^{* *} \\
(0.016)\end{array}$ & $\begin{array}{l}0.699^{* *} \\
(0.019)\end{array}$ & $\begin{array}{l}0.613^{* *} \\
(0.028)\end{array}$ & $\begin{array}{l}0.551^{* *} \\
(0.029)\end{array}$ & $\begin{array}{l}0.550^{* * *} \\
(0.029)\end{array}$ & $\begin{array}{l}0.581^{* *} \\
(0.034)\end{array}$ \\
\hline South & $\begin{array}{l}-0.051 \\
(0.026)\end{array}$ & $\begin{array}{l}-0.054^{*} \\
(0.022)\end{array}$ & $\begin{array}{c}-0.056^{* *} \\
(0.020)\end{array}$ & $\begin{array}{l}-0.043 \\
(0.025)\end{array}$ & $\begin{array}{l}-0.035 \\
(0.022)\end{array}$ & $\begin{array}{c}0.011 \\
(0.020)\end{array}$ & $\begin{array}{c}0.010 \\
(0.020)\end{array}$ & $\begin{array}{c}0.000 \\
(0.021)\end{array}$ \\
\hline Central & $\begin{array}{l}-0.068^{*} \\
(0.033)\end{array}$ & $\begin{array}{l}-0.064 \\
(0.033)\end{array}$ & $\begin{array}{l}-0.072^{*} \\
(0.032)\end{array}$ & $\begin{array}{l}-0.061 \\
(0.033)\end{array}$ & $\begin{array}{l}-0.052^{*} \\
(0.023)\end{array}$ & $\begin{array}{c}0.006 \\
(0.023)\end{array}$ & $\begin{array}{c}0.004 \\
(0.024)\end{array}$ & $\begin{array}{l}-0.012 \\
(0.024)\end{array}$ \\
\hline North & $\begin{array}{c}-0.105^{* *} \\
(0.023)\end{array}$ & $\begin{array}{c}-0.107^{* *} \\
(0.023)\end{array}$ & $\begin{array}{c}-0.100^{* *} \\
(0.023)\end{array}$ & $\begin{array}{c}-0.102^{* *} \\
(0.023)\end{array}$ & $\begin{array}{c}-0.063^{* *} \\
(0.023)\end{array}$ & $\begin{array}{l}-0.013 \\
(0.019)\end{array}$ & $\begin{array}{c}-0.012 \\
(0.020)\end{array}$ & $\begin{array}{c}-0.019 \\
(0.021)\end{array}$ \\
\hline East & $\begin{array}{c}-0.225^{* *} \\
(0.032)\end{array}$ & $\begin{array}{c}-0.193^{* *} \\
(0.045)\end{array}$ & $\begin{array}{c}-0.175^{* *} \\
(0.025)\end{array}$ & $\begin{array}{c}-0.207^{* *} \\
(0.031)\end{array}$ & $\begin{array}{c}-0.173^{* *} \\
(0.029)\end{array}$ & $\begin{array}{l}-0.047 \\
(0.029)\end{array}$ & $\begin{array}{l}-0.049 \\
(0.028)\end{array}$ & $\begin{array}{l}-0.053 \\
(0.031)\end{array}$ \\
\hline Constant & $\begin{array}{l}0.257^{* * *} \\
(0.065)\end{array}$ & $\begin{array}{l}0.209^{* *} \\
(0.031)\end{array}$ & $\begin{array}{l}0.218^{* * *} \\
(0.020)\end{array}$ & $\begin{array}{l}0.243^{* *} \\
(0.062)\end{array}$ & $\begin{array}{l}0.194^{* * *} \\
(0.059)\end{array}$ & $\begin{array}{c}-0.668^{* *} \\
(0.126)\end{array}$ & $\begin{array}{c}-0.662^{* *} \\
(0.129)\end{array}$ & $\begin{array}{c}-0.484^{* *} \\
(0.138)\end{array}$ \\
\hline $\begin{array}{l}\text { Number of Observations } \\
\text { R-squared }\end{array}$ & $\begin{array}{c}221 \\
0.894\end{array}$ & $\begin{array}{c}221 \\
0.894\end{array}$ & $\begin{array}{c}221 \\
0.908\end{array}$ & $\begin{array}{c}221 \\
0.901\end{array}$ & $\begin{array}{c}221 \\
0.913\end{array}$ & $\begin{array}{c}221 \\
0.931\end{array}$ & $\begin{array}{c}221 \\
0.931\end{array}$ & $\begin{array}{c}221 \\
0.934\end{array}$ \\
\hline
\end{tabular}


Table E2: OLS estimates for number of teachers per 100 school-age children (all levels; 1980, 2000, 2012)

\begin{tabular}{|c|c|c|c|c|c|c|c|c|}
\hline & Kurdish & Gini & Conflict & Kurdish +1 & Kurdish + 2 & Kurdish +3 & Kurdish + 4 & Table 4, C1 \\
\hline Log of Kurdish \% t-1 & $\begin{array}{c}-0.757^{\text {*** }} \\
(0.124)\end{array}$ & & & $\begin{array}{c}-0.437^{* *} \\
(0.093)\end{array}$ & $\begin{array}{c}-0.397^{* *} \\
(0.093)\end{array}$ & $\begin{array}{c}-0.381^{* * *} \\
(0.081)\end{array}$ & $\begin{array}{c}-0.392^{* *} \\
(0.083)\end{array}$ & $\begin{array}{c}-0.399^{* *} \\
(0.087)\end{array}$ \\
\hline Gini coef. for land distr. $t-1$ & & $\begin{array}{c}-3.322^{* *} \\
(0.961)\end{array}$ & & & & & & $\begin{array}{c}0.247 \\
(0.440)\end{array}$ \\
\hline Log of fatalities prev. 10 years & & & $\begin{array}{l}-0.098 \\
(0.172)\end{array}$ & & & & & $\begin{array}{l}-0.008 \\
(0.061)\end{array}$ \\
\hline $5-14$ pop. gr. previous 10 years & & & & $\begin{array}{c}-0.253^{* *} \\
(0.030)\end{array}$ & $\begin{array}{c}-0.287^{* *} \\
(0.026)\end{array}$ & $\begin{array}{c}-0.232^{* *} \\
(0.022)\end{array}$ & $\begin{array}{c}-0.233^{* *} \\
(0.022)\end{array}$ & $\begin{array}{c}-0.236^{* * *} \\
(0.023)\end{array}$ \\
\hline Log of gdp pc t-1 & & & & & $\begin{array}{l}0.428^{* *} \\
(0.110)\end{array}$ & $\begin{array}{l}0.610^{* * *} \\
(0.105)\end{array}$ & $\begin{array}{l}0.559^{* * *} \\
(0.106)\end{array}$ & $\begin{array}{l}0.554^{* * *} \\
(0.108)\end{array}$ \\
\hline Log of pop. density $t-1$ & & & & & & $\begin{array}{c}-0.386^{* *} \\
(0.088)\end{array}$ & $\begin{array}{c}-0.422^{* * *} \\
(0.102)\end{array}$ & $\begin{array}{c}-0.423^{* *} \\
(0.099)\end{array}$ \\
\hline Urban t-1 & & & & & & & $\begin{array}{c}0.458 \\
(0.462)\end{array}$ & $\begin{array}{c}0.444 \\
(0.459)\end{array}$ \\
\hline $2000 \mathrm{dv}$ & $\begin{array}{l}2.013^{* *} \\
(0.061)\end{array}$ & $\begin{array}{l}1.813^{* * *} \\
(0.080)\end{array}$ & $\begin{array}{l}1.992^{* *} \\
(0.130)\end{array}$ & $\begin{array}{l}1.423^{* *} \\
(0.120)\end{array}$ & $\begin{array}{l}1.068^{* * *} \\
(0.124)\end{array}$ & $\begin{array}{l}1.217^{* *} \\
(0.111)\end{array}$ & $\begin{array}{l}1.187^{* * *} \\
(0.125)\end{array}$ & $\begin{array}{l}1.201^{* * *} \\
(0.143)\end{array}$ \\
\hline $2012 \mathrm{dv}$ & $\begin{array}{l}3.330^{* * *} \\
(0.081)\end{array}$ & $\begin{array}{l}3.003^{* *} \\
(0.094)\end{array}$ & $\begin{array}{l}3.191^{\text {*** }} \\
(0.087)\end{array}$ & $\begin{array}{l}2.479^{* * *} \\
(0.121)\end{array}$ & $\begin{array}{l}2.022^{* * *} \\
(0.136)\end{array}$ & $\begin{array}{l}2.222^{* * *} \\
(0.139)\end{array}$ & $\begin{array}{l}2.172^{* * *} \\
(0.153)\end{array}$ & $\begin{array}{l}2.187^{* * *} \\
(0.159)\end{array}$ \\
\hline South & $\begin{array}{c}0.109 \\
(0.253)\end{array}$ & $\begin{array}{c}0.050 \\
(0.319)\end{array}$ & $\begin{array}{l}-0.194 \\
(0.339)\end{array}$ & $\begin{array}{c}0.066 \\
(0.207)\end{array}$ & $\begin{array}{c}0.196 \\
(0.210)\end{array}$ & $\begin{array}{c}0.154 \\
(0.173)\end{array}$ & $\begin{array}{c}0.132 \\
(0.170)\end{array}$ & $\begin{array}{c}0.116 \\
(0.175)\end{array}$ \\
\hline Central & $\begin{array}{c}0.221 \\
(0.181)\end{array}$ & $\begin{array}{c}0.005 \\
(0.159)\end{array}$ & $\begin{array}{l}-0.094 \\
(0.171)\end{array}$ & $\begin{array}{l}-0.072 \\
(0.131)\end{array}$ & $\begin{array}{c}0.084 \\
(0.128)\end{array}$ & $\begin{array}{l}-0.036 \\
(0.132)\end{array}$ & $\begin{array}{l}-0.067 \\
(0.133)\end{array}$ & $\begin{array}{l}-0.077 \\
(0.132)\end{array}$ \\
\hline North & $\begin{array}{l}-0.108 \\
(0.146)\end{array}$ & $\begin{array}{c}0.017 \\
(0.170)\end{array}$ & $\begin{array}{c}0.117 \\
(0.162)\end{array}$ & $\begin{array}{c}-0.469^{* *} \\
(0.127)\end{array}$ & $\begin{array}{l}-0.277^{*} \\
(0.130)\end{array}$ & $\begin{array}{l}-0.165 \\
(0.118)\end{array}$ & $\begin{array}{l}-0.147 \\
(0.120)\end{array}$ & $\begin{array}{l}-0.151 \\
(0.121)\end{array}$ \\
\hline East & $\begin{array}{c}0.571 \\
(0.359)\end{array}$ & $\begin{array}{c}-0.750^{* *} \\
(0.262)\end{array}$ & $\begin{array}{l}-0.972^{* *} \\
(0.222)\end{array}$ & $\begin{array}{l}-0.058 \\
(0.244)\end{array}$ & $\begin{array}{c}0.302 \\
(0.288)\end{array}$ & $\begin{array}{c}0.166 \\
(0.239)\end{array}$ & $\begin{array}{c}0.143 \\
(0.243)\end{array}$ & $\begin{array}{c}0.135 \\
(0.247)\end{array}$ \\
\hline Constant & $\begin{array}{l}3.926^{* *} \\
(0.202)\end{array}$ & $\begin{array}{l}4.510^{* *} \\
(0.505)\end{array}$ & $\begin{array}{l}2.886^{* *} \\
(0.181)\end{array}$ & $\begin{array}{l}3.244^{* *} \\
(0.097)\end{array}$ & $\begin{array}{c}0.962 \\
(0.756)\end{array}$ & $\begin{array}{c}1.198 \\
(0.724)\end{array}$ & $\begin{array}{c}1.547^{*} \\
(0.757)\end{array}$ & $\begin{array}{c}1.486 \\
(0.750)\end{array}$ \\
\hline $\begin{array}{l}\text { Number of Observations } \\
\text { R-squared }\end{array}$ & $\begin{array}{c}229 \\
0.817\end{array}$ & $\begin{array}{c}229 \\
0.780\end{array}$ & $\begin{array}{c}229 \\
0.760\end{array}$ & $\begin{array}{c}229 \\
0.873\end{array}$ & $\begin{array}{c}229 \\
0.882\end{array}$ & $\begin{array}{c}229 \\
0.900\end{array}$ & $\begin{array}{c}229 \\
0.901\end{array}$ & $\begin{array}{c}229 \\
0.901\end{array}$ \\
\hline
\end{tabular}

Notes. Province-level clustered standard errors in parenthesis. ${ }^{*}, * *$ denote 5 and 1 percent confidence levels, respectively. 
Table F1. Correlation Matrix

\begin{tabular}{|c|c|c|c|c|c|c|c|c|}
\hline & Gini & Kurdish & Fatalities & $\begin{array}{l}\text { Boys-to- } \\
\text { girls }\end{array}$ & Urban & GDP pc & $\begin{array}{c}\text { Pop. } \\
\text { density }\end{array}$ & $\begin{array}{c}5-14 \\
\text { pop. gr. }\end{array}$ \\
\hline Gini coef. for land distr. & 1 & & & & & & & \\
\hline Log of Kurdish \% & 0.600 & 1 & & & & & & \\
\hline Log of fatalities prev. 10 years & 0.211 & 0.525 & 1 & & & & & \\
\hline Boys-to-girls ratio dummy & 0.212 & 0.292 & 0.285 & 1 & & & & \\
\hline Urbanization rate & 0.074 & 0.093 & 0.180 & 0.000 & 1 & & & \\
\hline Log of gdp pc & -0.279 & -0.400 & -0.224 & -0.207 & 0.650 & 1 & & \\
\hline Log of pop. density & -0.073 & -0.232 & -0.135 & -0.039 & 0.530 & 0.547 & 1 & \\
\hline $5-14$ pop. gr. previous 10 years & 0.511 & 0.321 & -0.122 & 0.133 & -0.110 & -0.270 & 0.119 & 1 \\
\hline
\end{tabular}

